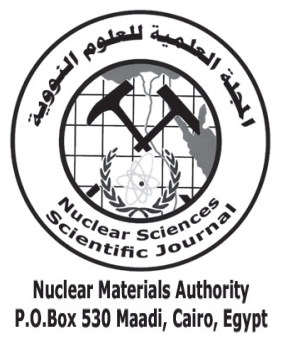

ISSN 2314-5609

Nuclear Sciences Scientific Journal

vol. 2, p 99 - 122

2013

\title{
URANIUM MINERALIZATION HOSTED BY THE PALEOZOIC SANDSTONES AT SOUTHWEST SINAI, EGYPT
}

\author{
AHMED E. A. SHATA \\ Nuclear Materials Authority, P.O. Box 530, El-Maadi, Cairo, Egypt
}

\begin{abstract}
The uranium mineralization hosted by the Paleozoic sandstones is one of two types: The first is the syngenetic continental/littoral paleoplacers (refractory Th-U bearing minerals) which were detritus from far distant source rocks. These minerals are mainly uranothorite, thorite, zircon, cheralite, chevickinite, davidite, xenotime, and monazite. Meander loops and channels with deep scours appear to be the most favourable sites for this mineralization. The second is the tectonic-lithologic sandstone-type uranium deposits being epigenetic U-enrichment within the sandstones along the permeable fault zones. It contains saleeite, sodium-meta-autunite, threadgoldite and uvanite in addition to REE-bearing iron and aluminium phosphate minerals; vivianite, goyazite, wavellite, florencite and plumbogummite. The studied Paleozoic sandstones are enriched in $\mathrm{P}_{2} \mathrm{O}_{5}, \mathrm{Al}_{2} \mathrm{O}_{3}, \mathrm{Fe}_{2} \mathrm{O}_{3}, \mathrm{TiO}_{2}, \mathrm{Zr}, \mathrm{Y}, \mathrm{Sr}, \mathrm{Ni}, \mathrm{Cr}, \mathrm{Zn}, \mathrm{Pb}, \mathrm{Ba}, \mathrm{V}, \mathrm{U}$ and Th relative to the Upper Continental Crust (UCC). This enrichment may be attributed to the high content of zircon, iron oxyhydroxides, phosphate minerals (either uranium or aluminium phosphates) and iron titanium detrital minerals. Ga, W, Sn and REE show considerable concentrations in the radioactive Cambro-Ordovician sandstones at Gabal Hemeyir and Ras Millan areas.

The tectolithologic sandstone-type uranium deposits is occurring in significant quantities in the ferruginous sandstones of El Adedia Formation at both Gabal Hemeyir and south Wadi El Sahu localities as well as its equivalent sandstones of Araba Formation at Ras Millan area. These promising deposits represent important U-resources in southwest Sinai. The tectolithologic U-type deposits are stacked as discordant bodies through more than one stratigraphic horizon at Gabal Hemeyir, south Wadi El Sahu and Ras Millan areas. The importance of these localities for uranium mineralization is related to possible presence of reduced environment along these fault zones.
\end{abstract}

\section{INTRODUCTION}

The sandstone-type $\mathrm{U}$ deposits constitute about $18 \%$ of world $U$ resources being one of the main U mineralization types in the USA, Australia, Niger, South Africa, and central Asia (IAEA, 1996; Hobday and Galloway, 1999; World Nuclear Association, 2009). The large-scale prospecting and exploitation of sandstone-type uranium deposits were developed in America and in the former Soviet Union beginning in 1952 (Finch, 1967; Galloway, 1979; Langmuir, 1978), when the first sandstone-type uranium deposit in the world was discovered in Uchquduq, Uzbekistan. The $\mathrm{U}$ ore in these deposits accumulated within medium to coarse-grained sandstone beds in localized reduced environments. These deposits occur along permeable fault zones, discordant to strata with linguiform impregnation within the adjacent clastics. Uranium may form rather thick ore bodies which are referred also to as stack deposits when derived from its sources and re-distributed within the contiguous sediments (Dahlkamp, 1978). 
The Paleozoic succession (up to $320 \mathrm{~m}$ thick) in southern Sinai forms the basal units of the sedimentary sequence and unconformably overlies the Pre-Cambrian basement rocks. These fluvial-continental basal units separated from the underlying uplifted Precambrian basement rocks by a conspicuous unconformity marked by the presence of persistent basal conglomerates. The Paleozoic rocks in Sinai have been classified by many authors (e.g. Ball, 1916; Soliman and Abu El Fetouh, 1969a; Said, 1971; Issawi et al., 1981; Kora, 1984; El Agami, 1996; Wanas, 2011). Said (1971) subdivided the Paleozoic rocks in Sinai (Abu Durba area; Fig.1) into the preCarboniferous Araba and Naqus Formations and the Carboniferous Abu Durba Formation. Issawi et al. (1981) classified the Paleozoic sequence in Sinai (especially at Wadi Feiran area) into five mappable rock units. These units are from base to top: the Araba, Naqus, Abu Durba, Ahemir and Qiseib Formations. The name Araba Formation was given by Hassan (1967:In Said, 1971) to describe the Lower Paleozoic sediments in Abu Durba area. It has been applied for regional use of the Cambrian strata in Sinai by Klitzsch (1990). Weissbrod (1969), Omara (1972), El Beleity et al. (1986), Seilacher (1990) and Klitzch, (1990) assigned an Early Cambrian age for the Araba Formation, while Issawi and Jux (1982) and Kora (1984) extend its age to cover the Cambro-Ordovician. Kora (1984) revised the classification of the Carboniferous sequence of Soliman and Abu ElFetouh (1969a) that immediately overlies the basement complex in the Um Bogma area. He assigned the Sarabit El-Khadim, Abu Hamata, Naseib and Adedia Formations to the CambroOrdovician, while the Um Bogma and Abu Thora Formations were assigned to the lower Carboniferous. Akarish and El Gohary (2008) incorporated mineralogy and chemical composition of the lower Paleozoic sandstones in East Sinai to disclose their provenance and tectonic setting. Wanas (2011) classified the lower Paleozoic rock units in Egypt including Sinai Peninsula. This classification includes surface units (Taba, Araba and Naqus Formations) and its equivalent subsurface rock units (Shifa, Kohla and Basur Formations).

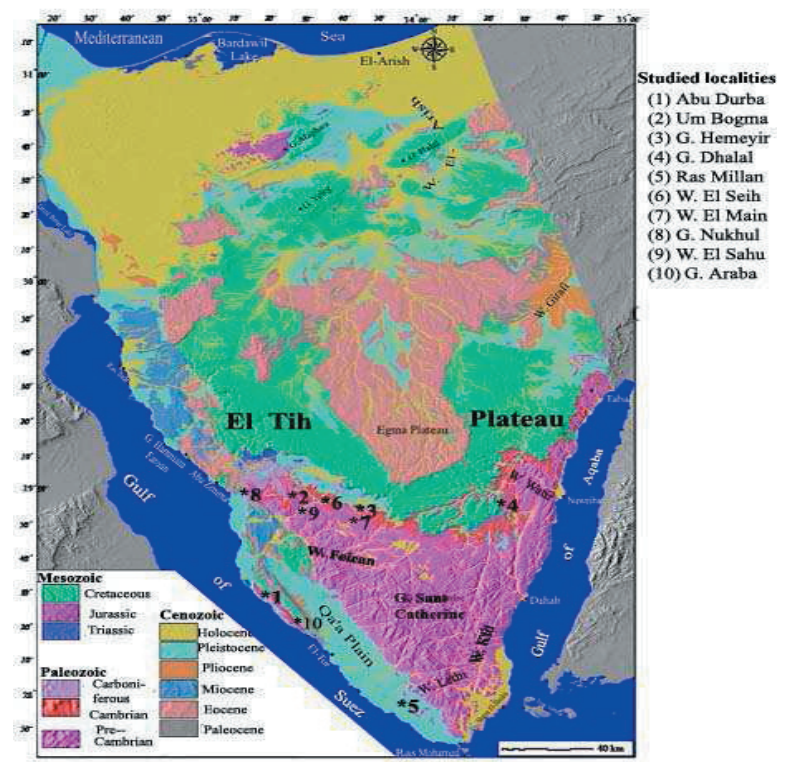

Fig. 1: Simplified geologic-geomorphic map showing the distribution of Paleozoic rocks and the studied localities in southwest Sinai 
The Paleozoic clastic rocks in Sinai were studied in detail from the radioactivity point of view by many authors (e.g. Abdel Monem et al., 1958; El Sokkary, 1971; El Aassy et al., 1986; Afifi, 1991; El Agami, 1996; El Kammar et al., 1997; Shata, 2002 \& 2004; El Afandy et al., 2010; Shata et al., 2011). Afify (1991) suggested that the uranium mineralization in Wadi Naseib (Um Bogma area) belongs to the sandstone-type uranium deposits. El Agami (1996) divided the uranium deposits in the Paleozoic rocks in Sinai to three types; paleoplacers, epigenetic and surficial uranium deposits. Shata (2004) inferred the existence of mobilized and trapped uranium ore bodies at the intersection localities between the NW and the SE fault lines at Ras Millan area. El Afandy et al., (2010) explained the distribution of major, trace elements and radionuclides in the light of the geochemical and radioactive characteristics of Abu Thora Formation. Shata et al., (2011) stated that the radioactivity of El Adedia Formation at Ramlet Hemeyir area is controlled mainly by the detrital and authigenic heavy mineral grains.

This work deals with the metallogenic charateristics of the sandstone-type uranium deposits in the Paleozoic sandstones of southwest Sinai from aspects of uranium source, geochemistry and mineralogy as well as the geochemical and mineralogical factors controlling the radioactivity in these sandstones.

\section{GEOLOGIC SETTING AND DEPOSITIONAL FACIES}

The Paleozoic rocks overlie non-conformably the Precambrian basement rocks in southwest Sinai. These basement rocks represent the northern extremity part of Arabian-Nubian Shield. The Paleozoic rocks are differentiated into Cambrian-Ordovician clastic sequence, lower Carboniferous carbonate rocks and Upper Carboniferous to Permo-Triassic clastic sequence (Fig.2a). The Paleozoic sandstones exposures are distributed mainly in southwest Sinai in Um Bogma (Figs. 2b,c), Gabal Dhalal area as a strip separating the crystal- line area of southern Sinai from Mesozoic and Tertiary rocks of El Tih and Egma Plateaux of central Sinai (Fig.1). These exposures exist either as small bodies resting on the top of high mountains, peneplained basement rocks or as down-faulted blocks against crystalline basement mountains. The Paleozoic exposures are also exposed in the extreme southwestern area of Sinai; in the foothills of Gabal Abu Haswa (Abu Durba area) and Gabal Araba; in the downstream part of Wadi Feiran and in the extreme southwest corner of Sinai; at the plain between El Tor and Ras Mohammed in the area known as Ras Millan (Fig.1).

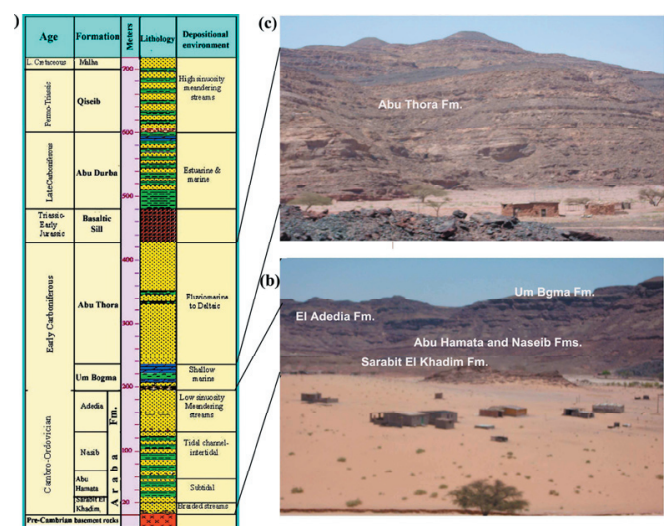

Fig.2: Stratigraphy of the Paleozoic succession in southwest Sinai (a); annotated outcrop photograph in Um Bogma area showing in detail its Cambro-Ordovician sandstones Formations, including Sarabit El-Khadim, Nasieb and Abu-Hamata and Adedia Formations (b) and lower Carboniferous Abu Thora Formation (c)

The radioactive polymictic conglomerate bed is well extended in Wadi Qarqur, Wadi Um Gidy, Wadi Imlieh (tributaries from Wadi El Main; Fig.1) and Wadi El Main which are correlated with the high radioactive polymictic conglomerate lens of Gabal Nukhul. The basal conglomerate units rest directly on the weathered basement rocks (Figs. 3\&4) ranging in thickness from $60 \mathrm{~cm}$ (Wadi Main) to $2.0 \mathrm{~m}$ (Gabal Nukhul, Wadi Qarqur and Gabal Adedia). It is not continually outcropped allover the studied localities. It appears in some areas and missed in others, whereas the overlying sandstone and siltstone units continually outcropping directly over the basement rocks. The basal conglomerate lenses are composed 
of rounded to sub-rounded grains of smoky quartz (Gabal Nukhul and Wadi Qarqur areas), rounded feldspars grains, sub-angular biotite grains, sub-rounded granitic, quartzite rock fragments and detritus Th-bearing mineral grains (Figs.5\&6). Kaolinite and hematite are the main interstitial constituents filling pore spaces between the components of conglomerate. The variability in texture and composition indicates that these conglomerates are of multiple sources. The morphology of the conglomerate beds resembles channel lag and grained braided bar deposits (Rust, 1972). While the planar cross-bedded quartz arenite are the deposits of sand braided bars (Cant, 1978).

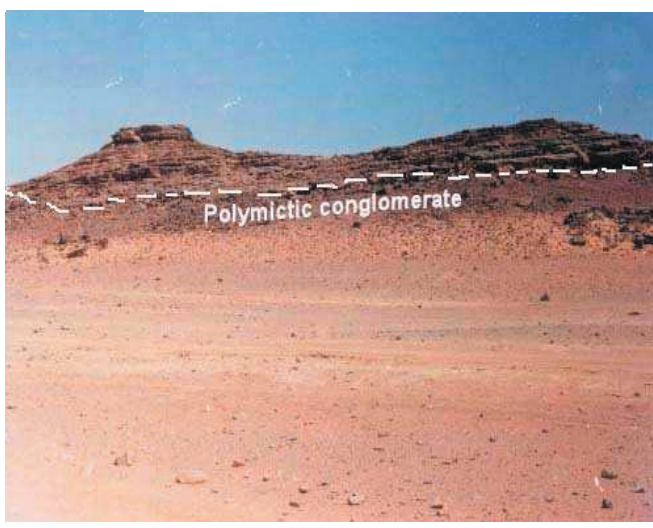

Fig.3: Polymictic basal conglomerate directly overlying the basement rocks at Wadi Qarqur

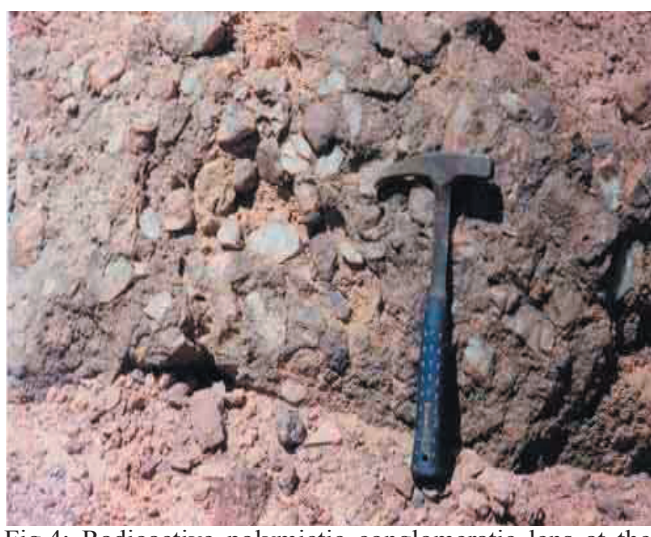

Fig 4: Radioactive polymictic conglomeratic lens at the base of Araba Formation, Wadi El Main area

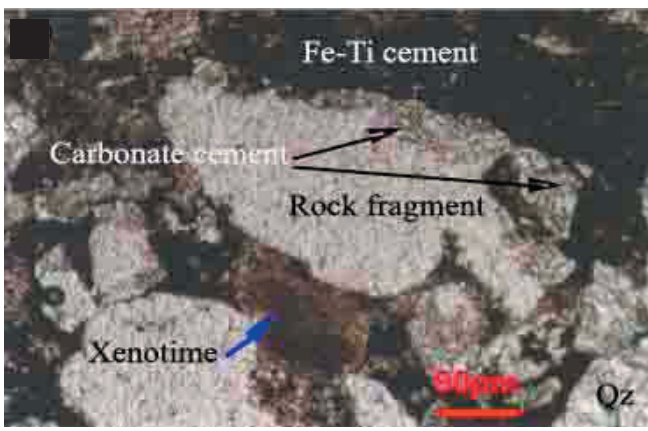

Fig.5: Rock fragments, xenotime and quartz cemented with carbonates (pointed by arrows), iron oxides and Fe-Ti cements in the conglomerate of Wadi Nukhul, ppl

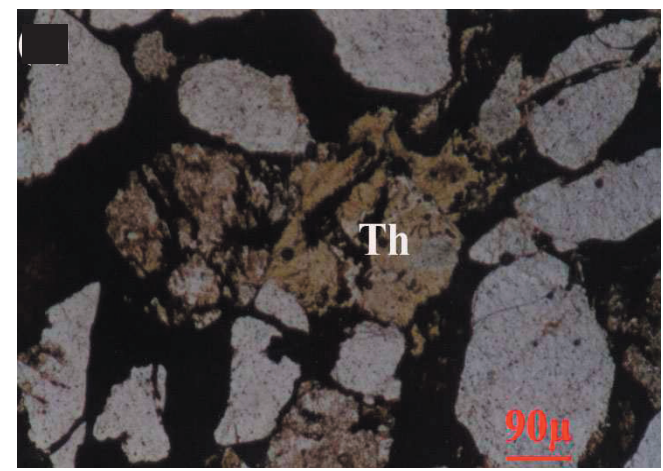

Fig. 6: Corroded thorite grains (Th) interspaces the quartz grains, Wadi Nukhul, ppl

The Cambro-Ordovician sandstones are mainly related to Araba and Naqus Formations. In Ras Millan area these sandstones are faulted contact with fine to medium, alkali granitic rocks in fault zone extended along more than $\sim 12 \mathrm{~km}$. Topographically, Ras Millan area is a featureless alluvial plain rising gently from sea level to about 400m high at the edge of the Precambrian massif. Spatially, Ras Millan plain lies in the structural domain suffering the strains resulting from the Gulf of Suez rifting in Oligo-Miocene age and that from the Gulf of Aqaba transform displacement in Plio-Pliestocene age. The effect of these two rifting led to the present, two intersecting fault systems which controlled the present hogback landforms dispersed in this coastal plain. These landforms consist of coarse clastics of Nubian facies dipping steeply to the west by the effect of the two intersecting NW and NE fault systems. 
The Araba Formation non-conformably overlies the kaolinized granite of the Precambrian basement rocks and conformably underlies the Naqus Formation (Fig.7a). It is mainly composed of sandstones and siltstones with intercalations of pebbly sandstones and conglomerates. The base of Araba Formation consists of kaolinized quartzitic conglomerate bed varies from 0.5 to $2 \mathrm{~m}$ in thickness (Fig.7b). Whereas the upper part is characterized by large scale-tabular and trough cross-bedding. It is reddish, very fine sand sized and contained a huge amount of black sand lenses (paleoplacers) which equivalent to the topmost part of El Adedia Formation in Um Bogma area (Fig.7c).

The radioactive Cambro-Ordovician ferruginous sandstones are related to the topmost part of El Adedia Formation (Figs.7d,e,f,g). The lithostratigraphy of ElAdedia Formation at Gabal Um Hamd (Fig.8), Gabal Abu Triefia (Figs.8\&9) and Gabal Maghara (Figs.1\&8); the southwest area of Wadi El Sahu and in Gabal Hemeyir area are studied. In these localities El Adedia Formation reaches to $60 \mathrm{~m}$ in thickness and consists of fine to medium grained sandstones, partially pebbly with distinguished tabular and convolute cross-bedding. The topmost part of
El Adedia Formation (2-5m in thickness) consists of ferruginous pebbly sandstones, sandstones and siltstones (Fig.7f). It shows signs of lateritization mainly of iron and less alumina and consists of hematitic siltstones and clay (lateritic soil). This horizon represents the unconformity surface between El Adedia Formation and its overlying Um Bogma Formation. The radioactive ferruginous sandstones are mainly structurally controlled as those at Gabal Um Hamd - Gabal Um Karasy - Gabal Abu Treifia strip (Fig. 9); Gabal Hemeyir - Wadi El Khamila area and Gabal Maghara(Fig.10). The black sand lenses (paleoplacers) are dominant in the upper part of El Adedia Formation which existed in Gabal Um Bogma, Abu Hamata (Fig.11), Gabal Ghorabi (Gabal Hemeyir area) and Gabal Sad El Banat (Um Bogma area). They are correlated with those in the upper part of Araba Formation (Fig.12; Ras Millan area) whereas they are matched in their mineral contents. These black lenses contain huge concentration of heavy minerals (Figs.11-14) with little content of quartz grains.

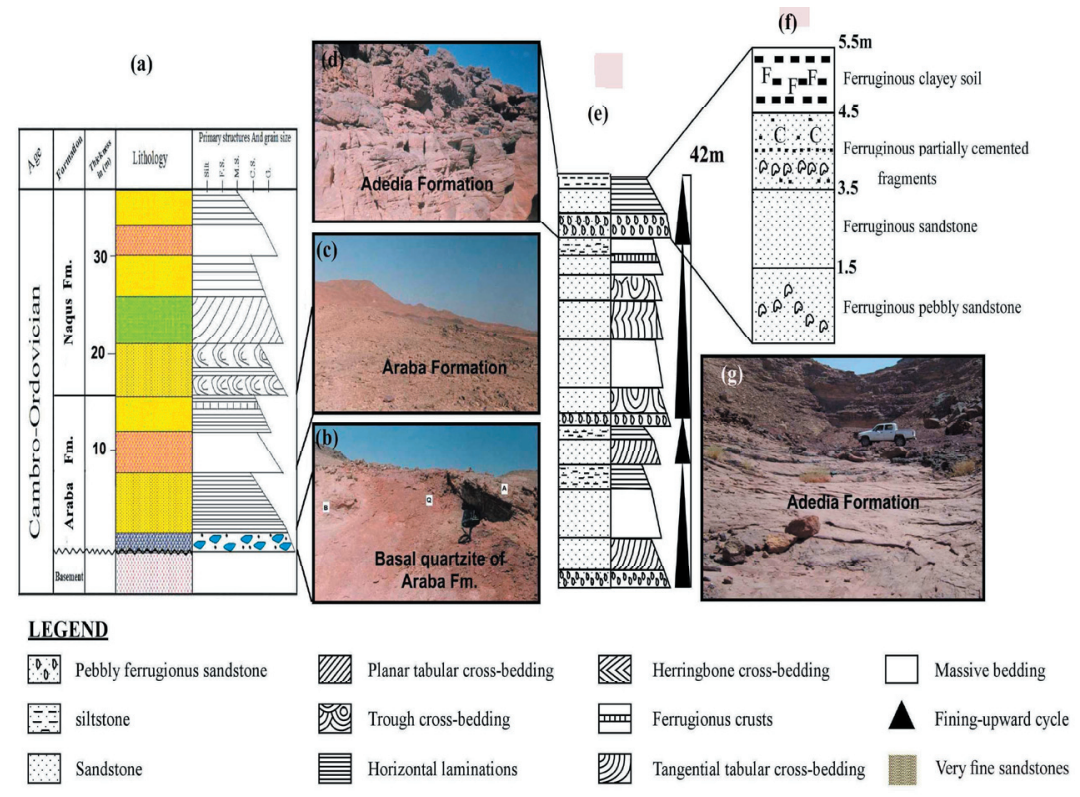

Fig.7: Lithostratigraphy of the Cambro-Ordovician succession in Ras Millan area (a) and annotated outcrop photographs showing in detail the radioactive sandstones of Araba Formation (b,c), and composite lithostratigraphic subdivisions of $\mathrm{El}$ Adedia Formation (e) and detailed lithostratigraphic section of its radioactive uppermost part (f) and its annotated outcrop photographs $(\mathrm{d}, \mathrm{g})$, south Wadi El Sahu area 


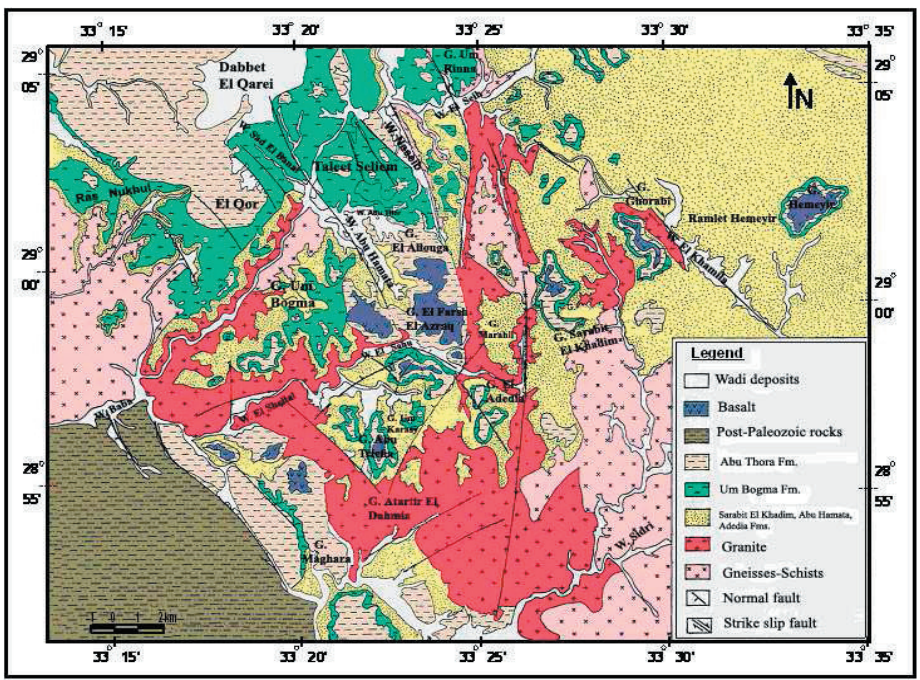

Fig.8: Geologic map of Um Bogma, G. Hemeyir region, southwest Sinai

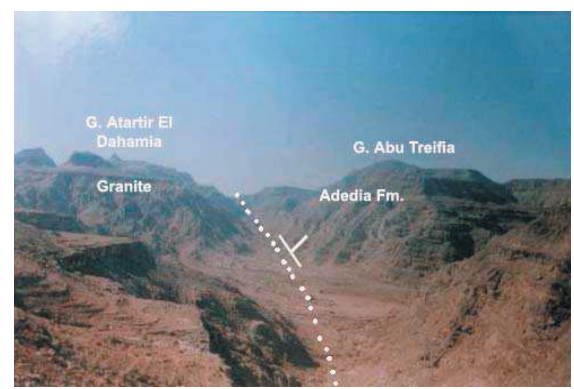

Fig.9: The long extension and fault control of anomalous ferruginous sandstones in Gabal Abu Triefia-south Wadi El Sahu area

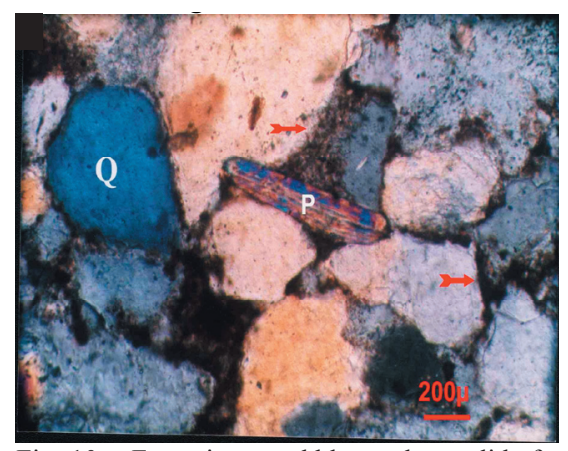

Fig. 10: . Ferruginous pebbly sandstone lithofacies showing mosaic of interlocking monocrystalline quartz grains $(\mathrm{Q})$ in a compacted texture of quartz arenite showing faint demarcation lines (arrows) between the primary grain and detrital apatite $(\mathrm{P})$ grains, $\mathrm{xpl}$

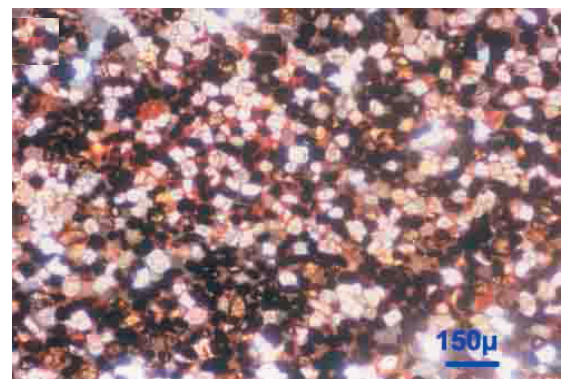

Fig. 11: Huge heavy minerals content in black sand lenses of Abu Hamata-Um Bogma area,ppl

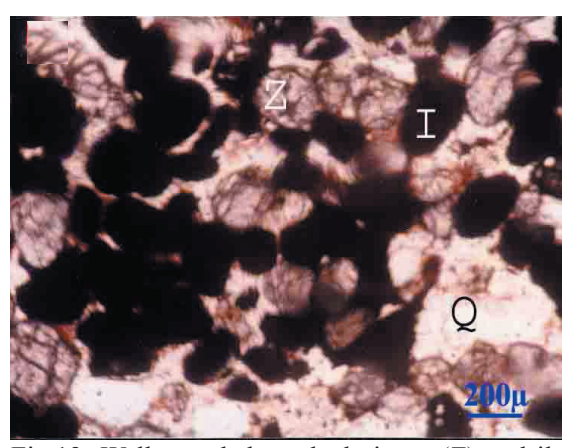

Fig.12: Well rounded cracked zircon $(\mathrm{Z})$ and ilmenite (I) heavy minerals content in the anomalous very fine sandstone, Ras Millan area, ppl 


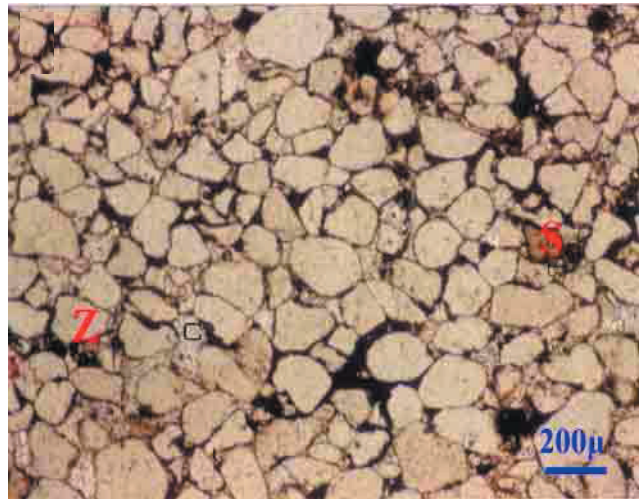

Fig.13: The very fine sandstones lithofacies of Araba Formation contains refractory $(Z)$ and secondary (S) minerals embedded in kaolinitic and ferruginated matrix, Wadi Lethi-Ras Millan area,ppl

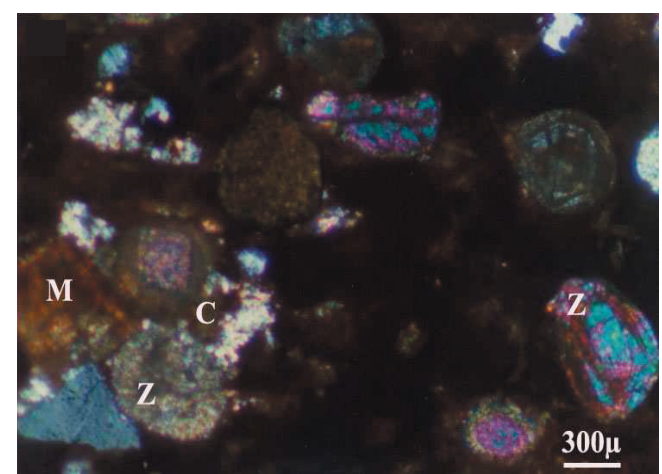

Fig.14: Corroded zircon $(\mathrm{Z})$ and monazite $(\mathrm{M})$ tiled by fibrous Fe-Ti cement (C), El Adedia Formation, xpl

The Lower Carboniferous Abu Thora Formation exposed only in Um Bogma area and its vicinities including Gabal Hemeyir area. Abu Thora Formation is unconformably overlying the marine lower Carboniferous Um Bogma Formation (Fig. 2a). It is generally composed of yellowish to pinkish white sandstones interbedded by varicolored siltstone and mudstone (middle unit). These mudstones grade laterally into carbonaceous shale with intercalated coal seams in some parts. The upper parts are almost snow white in color and friable (exploited for glass sand). Thin sandy conglomerate lens and gravelly layers are interbedded. Plant fossils including Lepidodendron and Sigillaria prints (Soliman and Abu El- Fetouh, 1969b) are recorded in the grey carbonaceous silty facies. The relative abundance of sandstone, siltstone and mudstone within Abu Thora Formation show great variations from one place to another. Three main lithofacies could be distinguished from base to top; the ferruginous and grimy white sandstone lithofacies; the varicolored siltstone and shale lithofacies; the milky white sandstone lithofacies. The ferruginous and grimy white sandstones may be laterally variated to mottled white and violet sandstones lithofacies. The youngest unit of Abu Thora succession is overlain with the Triassic-early Jurassic (Samoul et al., 1999) basalt sheet which reach to about $60 \mathrm{~m}$ in thickness at the top of Gabal El Farsh El Azraq (Figs. 2c\&8).

\section{MATERIALS AND METHODS}

One hundred and fifteen (115) samples were collected from the studied Paleozoic sandstones exposures in southwest Sinai. These samples represent the studied different radioactive lithofacies. The basal conglomerate lenses (12 samples), their samples are collected from trenched outcrops of Cambrian conglomerate at Gabal Nukhul, Wadi Qarqur, Gabal Adedia, Wadi Main, Wadi Um Gidy, and Wadi Imlieh. Eighteen samples were collected from the ferruginous sandstones at Wadi El Sahu area, 16 samples from Gabal Hemeyir area, 28 samples from the Araba sandstones at Ras Millan area and 41 samples from $\mathrm{Abu}$ Thora Formation at Um Bogma area. The geographic coordinates of the collected samples are illustrated in Tables $(1,2,3,4,5,6)$. The samples are grind and crushed. The very fine sand fractions $(<0.125 \mathrm{~mm})$ of these samples were subjected to heavy-mineral separation using bromoform (Sp. gr. $2.85 \mathrm{gm} / \mathrm{cm}^{3}$ ) and methylene iodide (Sp. gr. $\left.3.3 \mathrm{gm} / \mathrm{cm}^{3}\right)$. Electromagnetic separation using Frantz isodynamic separator, was carried out. The heavy mineral fractions were subjected to hand picking under the binocular microscope and the mineral identified by X-ray diffraction and Scanning Electron Microscope techniques. The X-ray diffraction technique (XRD) using PHILIPS PW 3710/31 diffractometer, scintillation counter; $\mathrm{Cu}$-target tube and Ni filter at $40 \mathrm{kV}$ 
and $30 \mathrm{~mA}$. The picked mineral grains were subjected to back-scattered electron using the Environmental Scanning Electron Microscope (ESEM) (model Philips XL30) supported with energy dispersive X-ray spectrometer (EDX) unit being used at $25-30 \mathrm{kV}$ accelerating voltage, 1-2 mm beam diameter and 60-120 second counting time. The samples were chemically analyzed for major and trace elements. The major oxides ( $\mathrm{wt} \%$ ) were measured using the conventional technique of Shapiro and Brannock, (1962). The trace elements concentrations (in ppm) were determined by the $\mathrm{X}$-ray fluorescence technique (XRF), using PHILIPS spectrometer with automatic sample changer PW 1510. Radiometric analysis for determination of eU, eTh, $\mathrm{Ra}$ and $\mathrm{K}$ using laboratory gamma-ray spectrometric technique. The radionuclide concentrations were determined by a multichannel analyzer gamma ray spectrometer which consists of NaI-Tl Bicron scintillation detector connected with NE-4658 amplifier and a high voltage power supply with HV digital display. The field radiometric measurements were carried out using GS-512 multi-channel instrument of Czech make. The same samples were analyzed for chemical uranium by using the spectrophotometer colorimetry techniques.

Petrographic, radiometric, chemical, mineralogical, X-ray diffraction and Scanning Electron Microscope studies were carried out in The Labs. of Nuclear Materials Authority (NMA), Egypt. Representative samples from the promising localities (W. Qarqur, G. Abu Trifia; south W. El Sahu, G. Hemeyir and Ras Millan areas) were chemically analyzed in Acme Laboratories of Canada. The major elements were determined by automated Xray fluorescence spectrometry (Siemen), with relative accuracy of $0.1 \%$ of major elements. The trace and rare earth elements were analyzed by Inductively Coupled Plasma-Mass Spectrometry (ICP-MS). Loss of ignition (LOI) is determined by weight difference after ignition at $1000^{\circ} \mathrm{C}$.

\section{RADIOACTIVITY}

The studied basal conglomerate lenses have anomalous radiometric uranium (eU) and thorium (eTh) contents (up to $157 \mathrm{ppm}$ $\mathrm{eU}$ and $2379 \mathrm{ppm}$ eTh). The activity of these clastics is attributed mainly to thorium content with subordinate to negligible uranium content (Table 1). In the anomalous conglomeratic lenses eTh ranges from 18 to 2379 ppm with an average of $500.3 \mathrm{ppm}$ and eU ranges from 4 to $157 \mathrm{ppm}$ with an average of $52.5 \mathrm{ppm}$. $\mathrm{eTh} / \mathrm{eU}$ ratio ranges from 1.3 to 18.2 with an average of 5.3. The Ra contents range from 6 to $91.1 \mathrm{ppm}$ with an average of $24.1 \mathrm{ppm}$. The $\mathrm{eTh} / \mathrm{eU}$ ratios reach up to $15.1,4.5,18.2$ at $\mathrm{Ga}-$ bal Nukhul, Gabal Adedia and Wadi Qarqur, respectively (Table 1 ). These high ratios can be attributed to the leaching of uranium during the long transportation distance from the parent rocks to the depositional braided channels. So, the chemical uranium (Uc) is depleted in this lithofacies (reach up to $40 \mathrm{ppm}$ at Wadi Qarqur).

Table 1: Radionuclides content and eTh/eU ratios of representative samples from the studied radioactive conglomerate lenses.

\begin{tabular}{|c|c|c|c|c|c|c|c|}
\hline \multirow[t]{2}{*}{ Locality } & \multirow[t]{2}{*}{ Sp. $\mathrm{N}_{0}$} & \multirow{2}{*}{\multicolumn{2}{|c|}{$\begin{array}{l}\text { eTh } \\
\mathrm{eU}\end{array}$}} & \multirow{2}{*}{\multicolumn{2}{|c|}{$\mathrm{eTh} / \mathrm{eU}$}} & \multicolumn{2}{|r|}{ Location } \\
\hline & & & & & & Latitude & Longitude \\
\hline \multirow{2}{*}{$\begin{array}{l}\text { Gabal } \\
\text { Nukhul }\end{array}$} & NKh.1 & 787 & 84 & 6 & 9.3 & $29^{\circ} 02^{\prime} 10^{\prime \prime} \mathrm{N}$ & $33^{\circ} 16^{\prime} \quad 33^{\prime \prime} \mathrm{E}$ \\
\hline & NKh.2 & 2379 & 157 & 23 & 15.1 & $29^{\circ} 02^{\prime} 12^{\prime \prime} \mathrm{N}$ & $33^{\circ} 16^{\prime} 31^{\prime \prime E}$ \\
\hline \multirow{2}{*}{$\begin{array}{l}\text { Wadi } \\
\text { Qarqur }\end{array}$} & Qr.1 & 412 & 41 & 6 & 10.0 & $28^{\circ} 57^{\prime} 30^{\prime \prime} \mathrm{N}$ & $33^{\circ} 47^{\prime} 46^{\prime E}$ \\
\hline & Qr.2 & 695 & 38 & 9 & 18.2 & $28^{\circ} 56^{\prime} 34^{\prime \prime} \mathrm{N}$ & $33^{\circ} 46^{\prime} 48^{\prime \prime} \mathrm{E}$ \\
\hline W.Imleih & Mn.1 & 438.4 & 27.1 & 30.4 & 16.2 & $28^{\circ} 55^{\prime} 34^{\prime \prime} \mathrm{N}$ & $33^{\circ} 43^{\prime} 11^{\prime \prime E}$ \\
\hline W.U.Um Gidy & Mn.2 & 169 & 16.7 & 91.1 & 10.1 & $28^{\circ} 55^{\prime} 47^{\prime \prime} \mathrm{N}$ & $33^{\circ} 46^{\prime} 48^{\prime \prime} \mathrm{E}$ \\
\hline $\begin{array}{l}\text { Gabal } \\
\text { Adedia }\end{array}$ & Ad.1 & 18 & 4 & 3 & 4.5 & $28^{\circ} 58^{\prime} 29^{\prime \prime} \mathrm{N}$ & $33^{\circ} 42^{\prime} 35^{\prime \prime} \mathrm{E}$ \\
\hline
\end{tabular}

The ferruginous sandstones in the topmost part of El Adedia Formation (2-5 $\mathrm{m}$ in thickness) have anomalous chemical U (Uc) contents reaching up to $3000 \mathrm{ppm}$ (Gabal Abu Triefia) in south Wadi El Sahu area. The anomalous ferruginous siltstones lithofacies at Gabal Um Hamd and Gabal Maghara as well as the ferruginous pebbly sandstones at Gabal 
Abu Triefia, Gabal Um Zobieb and Gabal Um Karasy (Fig.8) show high radiometric measurements and enriched in radionuclides $(\mathrm{eU}$, eRa and $\mathrm{K} \%$ ). The eU, eTh, eRa, K, eTh/eU, and $\mathrm{eU} / \mathrm{eRa}$ ratios in representative samples from these localities are listed in Table 2. The mineralized sandstones have high eU and $\mathrm{Ra}$ contents relative to $\mathrm{Th}$ and $\mathrm{K}$. The ferruginous pebbly sandstone lithofacies contain the highest concentrations of uranium and radium. Its eU contents reach up to $2040 \mathrm{ppm}$ (sample; A.T.25) with an average of 506 ppm. Its Ra contents reach up to $1528 \mathrm{ppm}$ with an average of $395.8 \mathrm{ppm}$. The high uranium and radium contents are attributed mainly to the presence of tongues and lenses of secondary Umineralization. The mineralized ferruginous sandstones characterized by very low eTh/eU ratios (ranging from 0.001 to 0.72 ; Table 2) due to their high uranium content relative to thorium. The sandstones at Gabal Abu Treifia, Gabal Um Hamd as well as Gabal Maghara localities have very low average $\mathrm{eTh} / \mathrm{eU}$ ratios $0.001,0.2$ and 0.18 respectively. The eTh/eU ratios suggest that uranium was removed from its sources and deposited in host sandstones

Table 2: Radionuclides contents and ratios of representative samples from the radioactive ferruginous sandstones at Wadi El Sahu-Gabal Maghara area

\begin{tabular}{|c|c|c|c|c|c|c|c|c|c|}
\hline \multirow[b]{2}{*}{ Locality } & \multirow[b]{2}{*}{$\begin{array}{l}\text { Sp. } \\
\text { No. }\end{array}$} & \multirow[b]{2}{*}{$\mathrm{eU}$} & \multirow[b]{2}{*}{ eTh } & \multirow[b]{2}{*}{$U_{c}$} & \multirow[b]{2}{*}{$\mathrm{Ra}$} & \multirow[b]{2}{*}{$D=U c l e U$} & \multirow[b]{2}{*}{ eThleU } & \multirow[b]{2}{*}{ Latitidude } & \multirow{2}{*}{$\begin{array}{l}\text { Lonatitur } \\
\text { Longitude }\end{array}$} \\
\hline & & & & & & & & & \\
\hline \multirow{6}{*}{$\begin{array}{l}\text { G. Abu } \\
\text { Trieffia }\end{array}$} & A.T. 8 & 371.4 & 40 & 867 & 296 & 2.3 & 0.11 & $28^{\circ} 58^{\prime} 12^{\prime \prime N} \mathrm{~N}$ & $33^{\circ} 23^{\prime} 07^{\prime \prime E}$ \\
\hline & A.T.9 & 171.4 & 43 & 750 & 362 & 4.4 & 0.25 & $28^{\circ} 58^{\prime} 10^{\prime \prime} \mathrm{N}$ & $33^{\circ} 23^{\prime} 11^{\prime \prime} \mathrm{E}$ \\
\hline & A.T.12 & 17.4 & 0.2 & 88 & 75 & 5.1 & 0.01 & $28^{\circ} 58^{\prime} 08^{\prime \prime} \mathrm{N}$ & $33^{\circ} 23^{\prime} 13^{\prime \prime} \mathrm{E}$ \\
\hline & A.T.15 & 154.2 & 0.1 & 35 & 53 & 0.23 & 0.001 & $28^{\circ} 58^{\prime} 05^{\prime \prime} \mathrm{N}$ & $33^{\circ} 23^{\prime} 15^{\prime \prime} \mathrm{E}$ \\
\hline & A.T.14 & 281.6 & 34.3 & 138.8 & 61 & 0.49 & 0.12 & $28^{\circ} 58^{\prime} 02^{\prime \prime} \mathrm{N}$ & $33^{\circ} 23^{\prime} 16^{\prime \prime E}$ \\
\hline & A.T.25 & 2040 & 75.3 & 3000 & 1528 & 1.47 & 0.34 & $28^{\circ} 58^{\prime} 15^{\prime \prime N}$ & $33^{\circ} 23^{\prime} 10^{\prime \prime} \mathrm{E}$ \\
\hline \multirow[t]{4}{*}{ Average } & & 506 & 32.2 & 813.1 & 395.8 & 2.72 & 0.14 & & \\
\hline & $\begin{array}{l}\text { Um. } \\
7\end{array}$ & 60.4 & 143.2 & 200 & 51 & 3.31 & 0.72 & $28^{\circ} 57^{\prime} 47^{\prime \prime} \mathrm{N}$ & $33^{\circ} 21^{\prime} 58^{\prime \prime} \mathrm{E}$ \\
\hline & Um.10 & 535.6 & 4 & 423 & 284 & 0.79 & 0.01 & $28^{\circ} 57^{\prime} 49^{\prime \prime} \mathrm{N}$ & $33^{\circ} 23^{\prime} 02^{\prime \prime E}$ \\
\hline & Um.13 & 304.1 & 41 & 236 & 51 & 0.8 & 0.17 & $28^{\circ} 57^{\prime} 52^{\prime \prime} \mathrm{N}$ & $33^{\circ} 22^{\prime} 00^{\prime \prime E}$ \\
\hline \multirow{5}{*}{$\begin{array}{l}\text { G. Um } \\
\text { Hamd }\end{array}$} & Um. & 1208.6 & 40 & 1058 & 502 & 0.9 & 0.04 & $28^{\circ} 57^{\prime} 50^{\prime \prime} \mathrm{N}$ & $33^{\circ} 21^{\prime} 55^{\mathrm{H}} \mathrm{E}$ \\
\hline & Um.12 & 510.3 & 72 & 207 & 72 & 0.41 & 0.35 & $28^{\circ} 57^{\prime} 38^{\prime \prime N} \mathrm{~N}$ & $33^{\circ} 23^{\prime} 00^{\prime \prime E}$ \\
\hline & Um.14 & 347.5 & 39.8 & 386 & 150 & 1.11 & 0.1 & $28^{\circ} 57^{\prime} 40^{\prime \prime N} \mathrm{~N}$ & $33^{\circ} 22^{\prime} 58^{\prime \prime E}$ \\
\hline & Um.11 & 177.6 & 15.4 & 292 & 76 & 1.64 & 0.1 & $28^{\circ} 57^{\prime} 39^{\prime \prime} \mathrm{N}$ & $33^{\circ} 21^{\prime} 24^{\prime \prime E}$ \\
\hline & Um.18 & 778 & 33 & 938 & 478 & 1.36 & 0.14 & $28^{\circ} 57^{\prime} 58^{\prime \prime} \mathrm{N}$ & $33^{\circ} 22^{\prime} 18^{\prime \prime} \mathrm{E}$ \\
\hline \multirow[t]{2}{*}{ Average } & & 490.3 & 48.6 & 467.5 & 208 & 1.29 & 0.2 & & \\
\hline & SR.1 & 130 & 70 & 96 & 55 & 0.74 & 0.54 & $28^{\circ} 54^{\prime} 37^{\prime \prime N}$ & $33^{\circ} 24^{\prime} 16^{\prime \prime} \mathrm{E}$ \\
\hline \multirow{3}{*}{$\begin{array}{l}\text { G. } \\
\text { Maghara }\end{array}$} & SR.2 & 270 & 30 & 245 & 86 & 0.91 & 0.11 & $28^{\circ} 54^{\prime} 42^{\prime \prime} \mathrm{N}$ & $33^{\circ} 24^{\prime} 18^{\prime \prime E}$ \\
\hline & SR.3 & 296 & 43 & 608 & 296 & 0.61 & 0.035 & $28^{\circ} 54^{\prime} 51^{\prime \prime} \mathrm{N}$ & $33^{\circ} 24^{\prime} 10^{\prime \prime E}$ \\
\hline & SR.4 & 263 & 21 & 697 & 362 & 1.31 & 0.04 & $28^{\circ} 54^{\prime} 33^{\prime \prime} \mathrm{N}$ & $\begin{array}{lll}33^{\circ} & 24^{\prime} & 02^{\prime \prime} \mathrm{E}\end{array}$ \\
\hline Average & & 239.8 & 41 & 411.5 & 199.8 & 0.9 & 0.18 & & \\
\hline
\end{tabular}

with continuous recharge (Adams and Weaver, 1958). This is confirmed by the values of both Uc/eU and eU/eRa ratios (Table 2). The mineralized sandstones show positive radioactive disequilibrium (Uc/eU ratios averag 2.33 and 1.29 in Gabal Abu Treifia and Gabal Um Hamd, respectively). Whereas the eU/eRa ratios exceed unity for most of the mineralized samples. All these radios suggest that $U$ was removed from its sources and recharged in the form of present tongues and lenses consist of secondary U-mineralization adsorbed on the weathering products represented in the kaolinite and iron oxyhydroxides concentrated in the fault zones.

At Gabal Hemeyir area (Fig.15a) the radioactive sandstones are related to three successive horizons including the topmost part of El Adedia Formation at Gabal Ghorabi, El Khamila (Fig.15b), Gabal Hemeyir and Ramlet Hemeyir localities. The second anomalous horizon is the ferruginous siltstone formed the lateritic soil directly overlying the first anomalous horizon. The third Ubearing horizon is the yellowish, violet and mottled white sandstones at the base of $\mathrm{Abu}$ Thora Formation (Uc reach up to $212 \mathrm{ppm}$ ). In these sandstones the eU/eTh ratio reflects the enrichment of uranium than thorium. The anomalous sector of Gabal Hemeyir locality is located in the eastern part of the Gabal between lat. $29^{\circ} 1^{\prime} 15^{\prime \prime}-29^{\circ} 1^{\prime} 35^{\prime \prime} \mathrm{N}$ and long. $33^{\circ} 32^{\prime} 30^{\prime \prime}-33^{\circ} 32^{\prime} 38^{\prime \prime} \mathrm{E}$. The radioactivity is controlled by a basic dyke in its contact with the ferruginous sandstones. This basic dyke reaches about $5 \mathrm{~m}$ in width and cutting the successive stratigraphic horizons of Gabal Hemeyir including El Adedia and Abu Thora formations. The eU content in the contact zone ranges from 2.1 to $490 \mathrm{ppm}$ while eTh content reaches to $75 \mathrm{ppm}$. The eU/eTh ratios reach up to 12.6 in the ferruginous sandstone and the Uc reaches up to 2040 ppm (sample; Hm.7). El Khamila locality occurred between lat. $29^{\circ} 0^{\prime} 25^{\prime \prime}$ to $29^{\circ} 0^{\prime} 32^{\prime \prime} \mathrm{N}$ and long. $33^{\circ} 31^{\prime}$ $38^{\prime \prime}$ to $33^{\circ} 31^{\prime} 46^{\prime \prime} \mathrm{E}$ (Fig.15b). The anomalous horizons at this locality show high eU/eTh 
ratio reaching up to 9.5 . The active horizons are related to the ferruginous sandstones and its overlying lateritic sediments $(0.5-2 \mathrm{~m}$ in thickness). The radioactive anomalies are controlled by major fault lines trending E-W and NW-SE such that exist in the Ras Rahia shear zone. The eU content ranges from 1.3 to $260 \mathrm{ppm}$ with an average of $21 \mathrm{ppm}$ and eTh content reaches to $50 \mathrm{ppm}$. The eU/eTh ratio shows high variability and reaching up to 9.7 in the ferruginous sandstones. The high radiometric measurements are predominantly attributed to secondary uranium enrichments (Uc reaches up to $672 \mathrm{ppm}$; sample Hm.1). At Gabal Ghorabi locality the high radioactivity is related to black sand lenses in the topmost
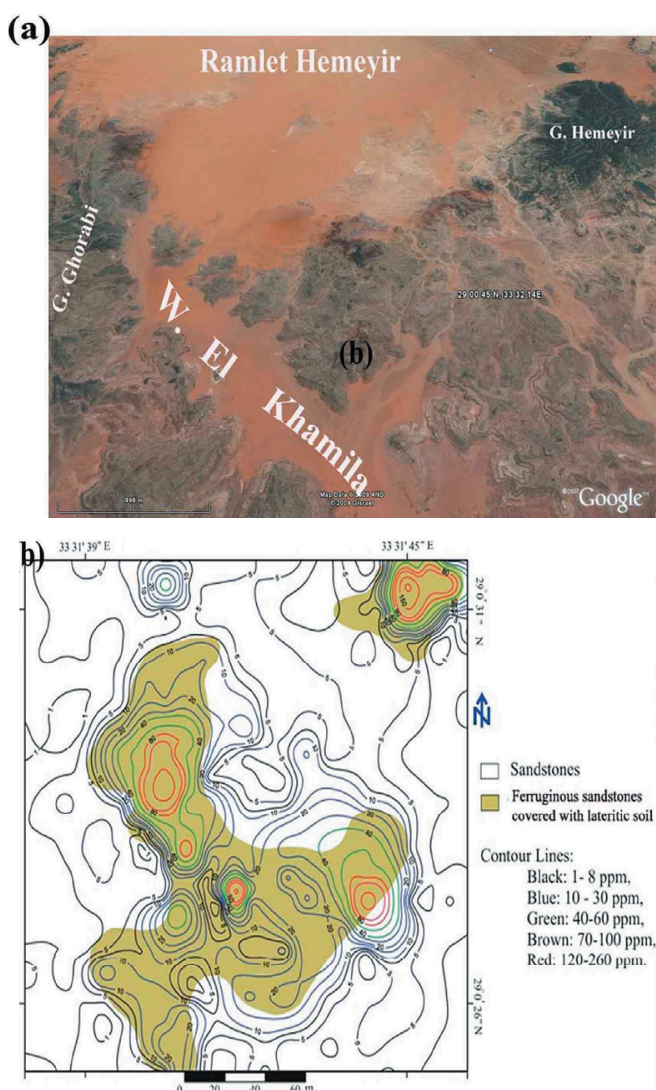

Fig. 15: Landsat image of G. Hemeyir area (a), equivalent uranium (eU) contour maps with geologic background of El Khamila (b) locality part of El Adedia Formation and the overlying lateritic soil. The first anomalous horizon is equivalent to those located in the same lithostratigraphic horizon at W. El Seih, Abu Hamata, G. Sad El Banat and other localities in Um Bogma area. In these black sand lenses thorium content is slightly higher than uranium. The highest eU/eTh occurs in the lateritic ferruginous siltstones constituting the most radioactive horizon in this locality. Its uranium contents (eU) reaches up to 521 ppm and Uc reach up to $650 \mathrm{ppm}$ (sample; LS.2),(Table 3). The Uc/eU ratio for the anomalous sandstones at Gabal Hemeyir area ranges from 0.49 to 27.5 with an average of 7.7 and the $\mathrm{eTh} / \mathrm{eU}$ ratio ranges from 0.12 to 0.44 with an average of 0.39 .

Table 3: Radionuclides contents and ratios in representative samples from the radioactive sandstones, Gabal Hemeyir area

\begin{tabular}{|c|c|c|c|c|c|c|c|c|}
\hline & $S p$ & & & & & & & Location \\
\hline Rock unit & No. & $\mathrm{el}$ & eTh & $U_{c}$ & $D=U c l e l$ & eTh/el & Latitude & \\
\hline \multirow{7}{*}{$\begin{array}{l}\text { Ferruginous } \\
\text { sandstones } \\
\text { in the top of } \\
\text { El Adedia } \\
\text { Formation }\end{array}$} & $\mathrm{Hm} .1$ & 432.4 & 147 & 672 & 1.6 & 0.34 & $29^{\circ} 01^{\prime} 22^{\prime \prime} \mathrm{N}$ & $33^{\circ} 32^{\prime} 35^{\prime \prime} \mathrm{E}$ \\
\hline & $\mathrm{Hm} \mathrm{C}$ & 389. & 171 & 667 & 171 & nM & $29^{\circ} 01^{\prime} 16^{\prime \prime} \mathrm{N}$ & $33^{\circ} 32^{\prime} 44^{\prime \prime E}$ \\
\hline & 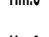 & 000.0 & & & & & $200^{\circ} 00^{\prime 2} 20^{\prime \prime} \mathrm{V}$ & $33^{\circ} 31^{\prime} 37^{\prime \prime E}$ \\
\hline & $\mathrm{Hm} \cdot \mathrm{g}$ & 2.6 & 2.9 & 35 & 13.5 & 1.12 & & \\
\hline & $H \mathrm{~m} .8$ & 260 & 40 & 485 & 1.87 & 0.15 & $29^{\circ} 00^{\prime} 26^{\prime \prime} \mathrm{N}$ & $33^{\circ} 31^{\prime} 59^{\prime \prime E}$ \\
\hline & $\mathrm{Hm} .7$ & 543 & 75 & 2040 & 27.2 & 0.14 & $29^{\circ} 01^{\prime} 30^{\prime \prime} \mathrm{N}$ & $33^{\circ} 32^{\prime} 37^{\prime \prime E}$ \\
\hline & Hm.15 & 281.6 & 34.3 & 138.8 & 0.49 & 0.12 & $29^{\circ} 01^{\prime} 32 " \mathrm{~N}$ & $33^{\circ} 32^{\prime} 31^{\prime \prime E}$ \\
\hline Average & & 318.2 & 78.4 & 673 & 7.7 & 0.39 & & \\
\hline \multirow{3}{*}{$\begin{array}{l}\text { Lateritic } \\
\text { siltstones }\end{array}$} & LS.1 & 418 & 71 & 550 & 1.32 & 0.17 & $29^{\circ} 00^{\prime} 11^{\prime \prime} \mathrm{N}$ & \\
\hline & LS.2 & 521 & 80 & 650 & 1.25 & 0.15 & & $33^{\circ} 31^{\prime} 44^{\prime \prime E}$ \\
\hline & LS.3 & 560 & 43 & 720 & 1.29 & 0.08 & & $42 " \mathrm{E}$ \\
\hline Average & & 499.7 & 64.7 & 640 & 1.28 & 0.13 & & \\
\hline $\begin{array}{l}\text { Mottled } \\
\text { sandstone }\end{array}$ & HE.1 & 35.3 & 31.4 & 100 & 2.83 & 0.89 & $29^{\circ} 0142^{\prime \prime} \mathrm{N}$ & $33^{\circ} 31^{\prime} 58^{\prime \prime} \mathrm{E}$ \\
\hline In the base & HE.2 & 78.8 & 25.1 & 160 & 2.03 & 0.32 & $29^{\circ} 01^{\prime} 37^{\prime \prime N}$ & $33^{\circ} 30^{\prime} 52^{\prime \prime E}$ \\
\hline of Abu & HE.3 & 31.1 & 19.6 & 110 & 3.54 & 0.63 & $29^{\circ} 01^{\prime} 43^{\prime \prime} \mathrm{N}$ & $33^{\circ} 29^{\prime} 54^{\prime \prime E}$ \\
\hline Formation & HE.4 & 10.5 & 8.3 & 95 & 9.1 & 0.79 & $29^{\circ} 02^{\prime}$ & $33^{\circ} 29^{\prime} 51^{\prime \prime E}$ \\
\hline Average & & 38.93 & 21.1 & 116.3 & 4.38 & 0.66 & & \\
\hline
\end{tabular}

The radioactive sandstones in Ras Millan area are the basal orthoquartzite (Uc up to $101.8 \mathrm{ppm}$ and Th up to $7433.1 \mathrm{ppm}$ ), the very fine sandstone in the topmost part (Uc up to $1016 \mathrm{ppm}$ and Th up to $8359 \mathrm{ppm}$ ) of Araba 
Formation. The eTh/eU ratios range from 1.68 to 25.6 with an average of 9.08 in the basal horizon while it ranges from 2.26 to 10.1 with an average of 6.25 in the overlying sandstones (Table $3 \& 4$ ). These high ratios reflect the huge content of detrital Th and Th-U bearing minerals as monazite, allanite, thorite, xenotime and davidite (see mineralogy section). In the very fine sandstones, the chemical uranium is higher than the radiometric one. The very high values of both $\mathrm{Uc}$ and $\mathrm{eTh} / \mathrm{eU}$ ratios in the same time can be attributed to the high concentration of U-bearing refractory and secondary authigenic uranium minerals. These different types of mineralization are recorded in petrographic studies (Fig. 13), XRD patterns and SEM investigations. The refractory minerals liberate uranium from their lattices during the metamictization and hydrothermal alteration processes along the permeable fault zones (Shata, 2004). The re-precipitation of the mobilized $\mathrm{U}^{6+}$ as secondary uranium mineralization are represented as saleeite, johannite and sodium meta-autunite in the faulted sandstones (samples; Rm.5, Rm.6, Rm.7). The loss of radium ( $\mathrm{Ra}$ ranges from 5.6 to $133.1 \mathrm{ppm}$ with an average of $58.2 \mathrm{ppm}$ ) as one of uranium daughters designates the radioactive disequilibrium state of these sandstones. The groundwater re-distributed the leached $U$ through the adjacent clastics along fault zone $(\sim 12 \mathrm{Km}$ in length). So the high values of both $\mathrm{eU} / \mathrm{Ra}$ and $\mathrm{Uc} / \mathrm{eU}$ ratios confirm the further addition than removal of uranium. This explains the variable radioactive measurements along the extension of the fault zone, where the maximum radioactive measurements were located at the downstream of Wadi Lethi ( $\mathrm{eTh}=3380.2 \mathrm{ppm}$ and $\mathrm{eU}=449.8 \mathrm{ppm}$ ). The sandstones far from the fault zone are slightly enriched in uranium than thorium (Uc reach up to $100 \mathrm{ppm}$ ). The importance of this zone for uranium mineralization is related to its possible occurrence of reduced environment along fault zone. Reduction may be produced by $\mathrm{H}_{2} \mathrm{~S}$-rich hydrothermal fluids and others ascending from deep hydrocarbon reservoirs of the very close Ras Garra oil field.
Table 4: Radionuclides contents and ratios of representative samples from the radioactive sandstones of Araba Formation, Ras Millan area

\begin{tabular}{|c|c|c|c|c|c|c|c|c|}
\hline \multirow[t]{2}{*}{ ck unit } & \multirow{2}{*}{$\begin{array}{l}\text { Sp. } \\
\text { No. }\end{array}$} & \multirow{2}{*}{\multicolumn{2}{|c|}{ eU }} & \multirow{2}{*}{\multicolumn{2}{|c|}{$c \mathrm{D}=\mathrm{UcleU}$}} & \multirow[t]{2}{*}{ eThel } & \multicolumn{2}{|r|}{ Location } \\
\hline & & & & & & & Latitude & Longitude \\
\hline \multirow{5}{*}{$\begin{array}{l}\text { Sandstones } \\
\text { of top } \\
\text { Araba } \\
\text { Formation }\end{array}$} & R.m.6 & 334.2 & 3380.2 & 360 & 1.1 & 10.1 & $27^{\circ} 59^{\prime} 30^{\prime \prime} \mathrm{N}$ & $3^{\circ} 23^{\prime} 15^{\prime \prime}$ \\
\hline & m.7.7 & 449.8 & 3146.7 & 1016 & 2.3 & 7.0 & $27^{\circ} 59^{\prime} 222^{\prime \prime N}$ & $33^{\circ} 22^{\prime} 51^{\prime \prime}$ \\
\hline & & 89.2 & 494.8 & 100 & 1.12 & 5.6 & $27^{\circ} 59^{\prime} 3$ & $3^{\circ} 22^{\prime}$ \\
\hline & $\begin{array}{r}\text { R.m.1 } \\
0\end{array}$ & & & & & & & \\
\hline & R.m.8 & 38.8 & 87.8 & 33 & 0.9 & 2.3 & $27^{\circ}$ & $33^{\circ} 22^{\prime} \quad 58^{\prime \prime}$ \\
\hline \multirow[t]{2}{*}{ erage } & & 228 & 7.4 & 377.3 & 1.4 & 5 & & \\
\hline & R.m.1 & 29.1 & 74.9 & 27 & 0.93 & 2.6 & 27056 & $33^{\circ} 58^{\prime} 52^{\prime \prime} \mathrm{E}$ \\
\hline \multirow{4}{*}{$\begin{array}{l}\text { Basal } \\
\text { kaolinized } \\
\text { quartzite }\end{array}$} & R.m.2 & 52.3 & 371.9 & 53 & 1.01 & 7.12 & $27^{\circ} 5$ & $33^{\circ} 59^{\prime} 25^{\prime \prime} \mathrm{E}$ \\
\hline & R.m.3 & 52.8 & 87.8 & 28 & 0.53 & 1.7 & $27^{\circ} 59^{\prime} 36^{\prime \prime} \mathrm{N}$ & $33^{\circ} 56^{\prime} 38^{\prime \prime} \mathrm{E}$ \\
\hline & R.m.4 & 90.9 & 770 & 29 & 0.34 & 8.5 & $27^{\circ} 58^{\prime} 08^{\prime \prime} \mathrm{N}$ & $33^{\circ} 58^{\prime} 02^{\prime \prime E}$ \\
\hline & R.m.5 & 125.5 & 3207.5 & 963 & 7.7 & 25.6 & $27^{\circ} 59^{\prime} 11^{\prime \prime N}$ & $33^{\circ} 58^{\prime} 33^{\prime \prime} \mathrm{E}$ \\
\hline & & .12 & 2.4 & 220 & 2.1 & 91 & & \\
\hline
\end{tabular}

The most radioactive rock units in $\mathrm{Abu}$ Thora Formation are the varicoloured siltstones and carbonaceous shales (Table 5). The varicoloured siltstones show eU contents reach up to $162 \mathrm{ppm}$ at Taleet Seliem locality (Um Bogma area; Fig.8) with an average of $24.7 \mathrm{ppm}$. While eTh reaches up to $309 \mathrm{ppm}$ at El Khaboba locality with an average of 37.1 ppm. The eTh/eU ratio reaches up to 7.19 with an average of $1.91 \mathrm{ppm}$. The eU contents in the black carbonaceous shales range from 4 to $21 \mathrm{ppm}$ with an average of 9.72 ppm (the maximum value is at Ras Nukhul locality). While Ra reaches up to $17 \mathrm{ppm}$ in Ras Nukhul black carbonaceous shales with an average of $6.61 \mathrm{ppm}$. Some storm samples have Uc reach up to $380 \mathrm{ppm}$ at Ras Nukhul locality. The anomalous mottled sandstones in the base of Abu Thora Formation at Gabal Hemeyir have eTh/eU ratios range from 0.09 to 0.314 with an average of 0.19 . The $\mathrm{Uc} / \mathrm{eU}$ ratio ranges from 2.03 to 9.1 with an average of 4.4. The enrichment of uranium in this horizon exceeds thorium (Uc reaches up to 212 $\mathrm{ppm}$ ). The uranium gained from the upwelling of U-bearing groundwater in the permeable sandstones along fault zones and controlled by the basic dyke which act as barrier along the successive horizons of Gabal Hemeyir. 
Table 5: Average radionuclides concentration in different lithofacies of Abu Thora Formation

\begin{tabular}{cccccccc}
\hline $\begin{array}{l}\text { S. } \\
\text { No. }\end{array}$ & Lithofacies & eU & eTh & Ra & K\% & eTh/eU \\
\hline 1 & $\begin{array}{r}\text { Ferruginous } \\
\text { sandstones }\end{array}$ & 13.4 & 10.4 & 16.2 & 0.62 & 0.81 \\
\hdashline 2 & $\begin{array}{r}\text { Coal bearing } \\
\text { black shales }\end{array}$ & 9.72 & 19.78 & 6.61 & 0.36 & 2.12 \\
\hline 3 & $\begin{array}{r}\text { Varicolored } \\
\text { siltstones }\end{array}$ & 24.72 & 37.09 & 18.0 & 0.24 & 1.91 \\
\hdashline 4 & White sandstones & 6.0 & 2.83 & 1.16 & 0.035 & 1.5 \\
\hline
\end{tabular}

The field radiometric measurements and tracing of radioactive anomalies in Abu Thora Formation revealed that the structurally controlled sandstones ridges with NNW-SSE normal faults are enriched in uranium than thorium. These major structure lines facilitate the circulation of U-bearing meteoric groundwater in the permeable fault zones. The negative correlation $(r=-0.74)$ between the eTh/ $\mathrm{eU}$ ratios and Uc shows some enrichment of $\mathrm{U}$ relative to thorium during supergene alteration processes. The $\mathrm{Uc} / \mathrm{eU}$ ratios in most of the mineralized and non mineralized samples are greater than 1. It ranges from 0.09 to 58 with an average of 12.7. The mineralized samples have a ratio reach up to 52 . This indicates the presence of strong radioactive positive disequilibrium $(\mathrm{Uc} / \mathrm{eU}>1)$ and $\mathrm{U}$ has been transported recently and has not enough time for daughters to be created in these sediments (have low to moderate Ra content).

\section{MINERALOGY}

\section{Mineralogy of the Paleoplacers-Bearing Conglomerates and Sandstones}

Thorite $\left(\mathrm{ThSiO}_{4}\right)$ is the most abundant Thbearing minerals in the studied paleoplacers either in the basal conglomerates or black sand lenses (Table 6). It is directly associated with other detrital heavy minerals including abundant uranothorite $(\mathrm{Th}, \mathrm{U}) \mathrm{SiO}_{4}$, thorianite $(\mathrm{Th}, \mathrm{U}) \mathrm{O}_{2}$, monazite (Ce, Th, La) $\mathrm{PO}_{4}$, zircon $\mathrm{ZrSiO}_{4}$, xenotime $\mathrm{YPO}_{4}$ besides new minerals recorded for the first time in the basal conglomerates at W.Qarqur, W. Main and G. Nukhul. These new minerals are cheralite (Th, $\mathrm{Ca}, \mathrm{Ce})\left(\mathrm{PO}_{4}, \mathrm{SO}_{4}\right)$ of monazite group, chevikinite $(\mathrm{Ca}, \mathrm{Ce}, \mathrm{Th})_{4}(\mathrm{Fe}, \mathrm{Mg})_{2}(\mathrm{Ti}$, $\mathrm{Fe})_{3} \mathrm{O}_{22}$ and thorutite (Th, U, Ca) $\mathrm{TiO}_{2}$, (Table $6)$. The radioactive minerals essentially exist as inclusions in the framework rock fragments or through matrix and/or iron oxides and clay cement materials.

Table 6: Minerals of the separated heavy fractions from the basal conglomerates and black sand lenses

\begin{tabular}{|c|c|c|c|c|c|}
\hline \multirow{2}{*}{$\begin{array}{l}S . \\
N_{0}\end{array}$} & Sp.N & \multirow{2}{*}{ Mineral contents } & \multirow{2}{*}{ Lithology .. } & \multicolumn{2}{|r|}{ Location } \\
\hline & 0. & & & Latitude & Longitude \\
\hline 1. & NK.1 & Thorite, Anatasse, renotime & Polymictic conglomeratet lens of Wadi Nukhul & $29^{\circ} 02^{\prime} 10^{\prime \prime} \mathrm{N}$ & $33^{\circ} 16^{\prime} 33^{\prime \prime} \mathrm{E}$ \\
\hline 2. & NK.2 & Chevikinite, monazite, cheralite & Polymictic conglomerate lens of Wadil Wukhul & $290022^{\prime} 12^{\prime \prime} \mathrm{N}$ & $33^{\circ} 16^{\prime} 31^{\prime \prime} \mathrm{E}$ \\
\hline 3. & Qr.1 & Ziron, hemantite, rranothonite & Polymictic conglonerate of Wadi Qarqur & $28^{\circ} 57^{\prime} 30^{\prime \prime} \mathrm{N}$ & $33^{\circ} 47^{\prime} 46^{\prime \prime} \mathrm{E}$ \\
\hline 4. & Qr.2 & $\begin{array}{l}\text { Thorianite, uranothorite, ,ircon, } \\
\text { cassiterrite }\end{array}$ & Polygnicicic conglonerate of Wadi (araqur & $28^{\circ} 56^{\prime} 34^{\prime \prime} \mathrm{N}$ & $33^{\circ} 46^{\prime} 48^{\prime \prime} \mathrm{E}$ \\
\hline 5. & Qr.3 & $\begin{array}{l}\text { Ilmenororatile, quarte, thorite and } \\
\text { cherihnite }\end{array}$ & Polymictic conglomerate of Wadi Qarqur & $288^{\circ} 57^{\prime} 02^{\prime \prime} \mathrm{N}$ & $33^{\circ} 46^{\prime} 14^{\prime \prime} \mathrm{E}$ \\
\hline 6. & Mn.1 & Thorite, hemaitite, quartz & Polymiticic conglonerate of Wadi Main & $28^{\circ} 55^{\prime} 34^{\prime \prime} \mathrm{N}$ & $33^{\circ} 43^{\prime} 11^{\prime \prime} \mathrm{E}$ \\
\hline 7. & Mn.2 & Cassertite, arrou, hemantite, thorutitie & Polymicicic conglomerate of Wadi. Main & $288^{\circ} 55^{\prime} 47 " \mathrm{~N}$ & $33^{\circ} 46^{\prime} 48^{\prime \prime} \mathrm{E}$ \\
\hline 8. & AH.I & Thorite, anatasse, senotime & Black sand lens in Gahal (G.)Um Bogma & $29^{\circ} 00^{\prime} 11^{\prime \prime} \mathrm{N}$ & $33^{\circ} 20^{\prime} 10^{\prime \prime} \mathrm{E}$ \\
\hline 9. & Ad.1 & Quart, irivon, anatase & Oligomictic conglonerate lens of G..Adectia & $28^{\circ} 58^{\prime} 29^{\prime \prime} \mathrm{N}$ & $33^{\circ} 42^{\prime} 35^{\prime \prime} \mathrm{E}$ \\
\hline 10. & Lth.1 & Davidite & Blacksand lens in Waadi Letti & $277^{\circ} 59^{\prime} 38^{\prime \prime} \mathrm{N}$ & $33^{\circ} 23^{\prime} 08^{\prime \prime} \mathrm{E}$ \\
\hline 11. & Lth.2 & Allanite, irron, hemanatite & Blacks sand lens in Waat Letti & $277^{\circ} 55^{\prime} 30^{\prime \prime} \mathrm{N}$ & $33^{\circ} 23^{\prime} 00^{\prime \prime E}$ \\
\hline 12. & Lth.3 & Ziron, imenite, thonite & Black sand lens in Waai Letti & $27^{\circ} 39^{\prime} 32^{\prime \prime} \mathrm{N}$ & $33^{\circ} 22^{\prime} 59^{\prime \prime} \mathrm{E}$ \\
\hline 13 & Gh.1 & Zirron, allanite, hematite & Black sand lens in G. Ghorabi & $29022^{\prime \prime} 08^{\prime \prime} \mathrm{N}$ & $33^{\circ} 29^{\prime} 51^{\prime \prime E}$ \\
\hline
\end{tabular}

The black sand lenses framework grains consists of quartz grains less than $10 \%$. Most of arenite are heavy minerals concentrates include zircon, monazite, allanite $(\mathrm{Ce}, \mathrm{Ca}, \mathrm{Y}, \mathrm{U})($ $\mathrm{Al}, \mathrm{Fe})_{3}\left(\mathrm{SiO}_{4}\right)_{3}(\mathrm{OH})$, xenotime $\mathrm{YPO}_{4}$, ilmenite $\mathrm{FeTiO}_{3}$ and rutile $\mathrm{TiO}_{2}$ (Figs.11\&12). The refractory heavy minerals exist as black laminas which can be distinguished in hand specimens as well as in thin sections. Well rounded monazite and zircon are the most abundant minerals, in addition to xenotime, rutile, ilmenite, anatase $\mathrm{TiO}_{2}$, ilmenorutile $\mathrm{Fe}(\mathrm{Nb}, \mathrm{Ta})_{2} \mathrm{TiO}_{2}$, barite $\mathrm{BaSO}_{4}$ embedded and coated with 
hematite $\mathrm{Fe}_{2} \mathrm{O}_{3}$ and anatase cement. Monazite exists as well-rounded lemon yellow grain associated with rounded zoned and unzoned zircon grains. The cement materials occur as fibrous and radial or acicular grains (Fig. 14). The source of iron and titanium oxides cement is suggested to be from detrital ilmenite grains dissolution (Shata et al., 2011). Intrastratal solution and meteoric water accompanied by oxidizing conditions are the main factors controlling the alteration of the detrital ilmenite grains. The high uranium content in the studied conglomerates and sandstones hosting to paleoplacers is attributed to iron and titanium oxy-hydroxides cement as detected from SEM investigations. Some uranium has been released from the above Th-U bearing minerals and then fixed by sorption on Fe-Ti oxy-hydroxides cement.

The mineralogic investigations show that the paleoplacers hosted in the basal conglomerates and the black sand lenses of El Adedia Formation in Um Bogma, Gabal Hemeyir and Ras Millan areas, are matching in their heavy minerals content and may be detrital from the surrounding source rocks.

\section{Mineralogy of the Epigenetic U-Bearing Sandstones}

The X-ray diffraction analyses show that the principal minerals controlled the radioactivity of El Adedia and Araba ferruginous sandstones are mainly the uraniferous xenotime, allanite, euxenite (Y,Ca,Ce, U, Th)(Nb,Ta,Ti) ${ }_{2} \mathrm{O}_{6}$ as well as secondary $U$ minerals as saleeite $\mathrm{Mg}\left(\mathrm{UO}_{2}\right)_{2}\left(\mathrm{PO}_{4}\right)_{2} \cdot \mathrm{H}_{2} \mathrm{O}$ and becquirelite $\mathrm{CaU}_{6} \mathrm{O}_{19} .11 \mathrm{H}_{2} \mathrm{O}$ at Wadi El Sahu area (Fig.16); xenotime (Fig.17), allanite, fergusonite $\mathrm{YNbO}_{4}$, apatite $\mathrm{Ca}_{5}\left(\mathrm{PO}_{4}\right)_{3}(\mathrm{~F}, \mathrm{Cl}, \mathrm{OH})$, zircon as well as secondary $U$ minerals; uvanite $\left(\mathrm{UO}_{2}\right)_{2} \mathrm{~V}_{6} \mathrm{O}_{1 .} .15 \mathrm{H}_{2} \mathrm{O}$ and threadgoldite $\mathrm{Al}\left(\mathrm{UO}_{2}\right)_{2}\left(\mathrm{PO}_{4}\right)_{2}(\mathrm{OH}) \cdot 8 \mathrm{H}_{2} \mathrm{O}$ in Gabal Hemeyir area. While the radioactivity at Gabal Maghara locality is controlled mainly by xenotime and zircon. The iron oxides minerals are mainly magnetite $\mathrm{Fe}_{3} \mathrm{O}_{4}$ and goethite $\mathrm{Fe}_{2} \mathrm{O}_{3}$. $\mathrm{H}_{2} \mathrm{O}$ (Table 7). The identified threadgoldite (sample; LS.3) and uvanite (sample; Hm.5) constitute the secondary epigenetic uranium enrichment in these sandstones along fault zones. The principal minerals controlled the radioactivity of the Araba sandstones at Ras Millan area are zircon (Figs.18\&19), allanite (Fig.20), thorite, xenotime, monazite (Fig.21), davidite $\left(\mathrm{Fe}^{2+}, \mathrm{U}, \mathrm{Ca}, \mathrm{Zr}, \mathrm{Th}, \mathrm{Ce}\right)($ $\left.\mathrm{Ti}, \mathrm{Fe}^{3+}, \mathrm{V}, \mathrm{Cr}\right)_{3} \mathrm{O} . \mathrm{OH}$ as well as secondary $\mathrm{U}$ minerals as saleeite and sodium metaautunite $(\mathrm{Na}, \mathrm{Ca})\left(\mathrm{UO}_{2}\right)_{2}\left(\mathrm{PO}_{4}\right) \cdot 8 \mathrm{H}_{2} \mathrm{O}$ (Fig.22). The presence of these minerals together with its associates; rutile, ilmenite, ilmenorutile (Fig.23) and magnetite indicates some sort of placer deposits. The aluminium phosphate minerals; wavellite $\mathrm{Al}_{3}\left(\mathrm{PO}_{4}\right)_{2}(\mathrm{OH})_{2} .5 \mathrm{H}_{2} \mathrm{O}_{3}$, vivianite $\mathrm{Fe}_{3}\left(\mathrm{PO}_{4}\right)_{2} .8 \mathrm{H}_{2} \mathrm{O}, \quad$ goyazite $\mathrm{SrAl}_{3}\left(\mathrm{PO}_{4}\right) \mathrm{OH} . \mathrm{H}_{2} \mathrm{O}$, florencite $\mathrm{Ce}\left(\mathrm{PO}_{4}\right)_{2}(\mathrm{OH})_{6}$ (Fig.24), plumbogummite $\mathrm{PbAl}_{3}\left(\mathrm{PO}_{4}\right)_{2}(\mathrm{OH})_{5}$. $\mathrm{H}_{2} \mathrm{O}$ were recorded in the radioactive sandstones (Table 7) either in El Adedia or Araba formations (at Gabal Hemeyir, Wadi El Sahu, Gabal Maghara and Ras Millan areas; Table 7).

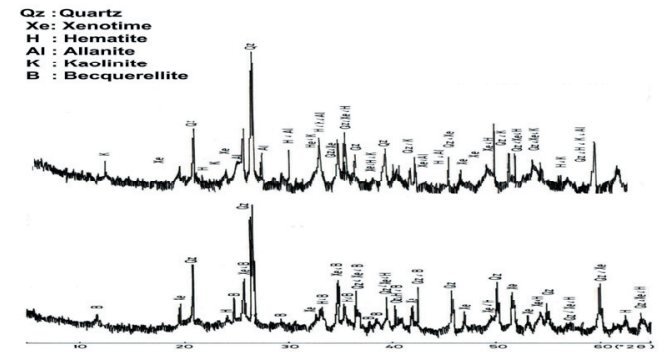

Fig. 16: XRD-diffractograms of representative samples of the studied ferruginous sandstones, Wadi El Sahu area

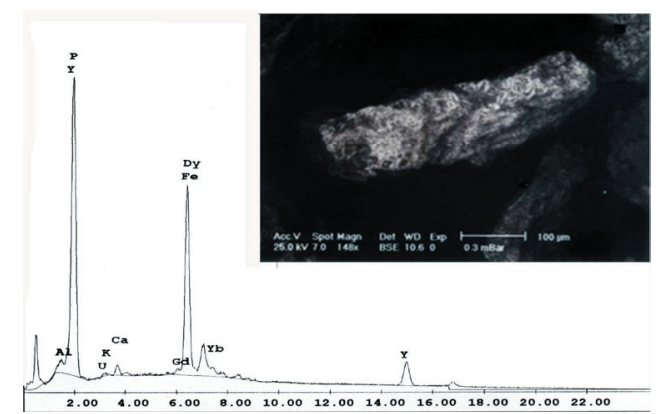

Fig. 17: Back scattered SEM \& EDX of Xenotime 
Table 7: Minerals of the separated heavy fractions from the sandstones of El Adedia and Araba formations at southwest Sinai

\begin{tabular}{|c|c|c|c|c|c|}
\hline $\mathrm{s}$. & & nts & Jith & & Location \\
\hline No. & 0. & was & & Latitiude & Longitude \\
\hline 1. & $\begin{array}{ll}\text { LS.3. } \\
\end{array}$ & Xenonime, threadgolditie, quartz & $\begin{array}{l}\text { Ferruginous sandstone at EI Khamila locality- - } \\
\text { Gabal (G.) Hemeyir area }\end{array}$ & $29^{\circ} 00^{\prime} 28^{\prime \prime} \mathrm{N}$ & $33^{\circ} 31^{\prime} 42^{\prime \prime} \mathrm{E}$ \\
\hline 2. & LS.2. & Kaolinite, anatasse, fregusonite, quartz & $\begin{array}{r}\text { Ferruginous sandstone at EI Khamila locality } \\
\qquad-G \text {. Hemeyir area }\end{array}$ & $29^{\circ} 00^{\prime} 30^{\prime \prime} \mathrm{N}$ & $33^{\circ} 31^{\prime} 44^{\prime \prime} \mathrm{E}$ \\
\hline 3. & $\mathrm{Hm} .3$ & Hemanatie, exonoine, kaolinite, goethite & Ferruginous sandstone at $G$. Hemeyir locality. & $29^{\circ} 01^{\prime} 34^{\prime \prime} \mathrm{N}$ & $33^{\circ} 32^{2} 30^{\prime \prime} \mathrm{E}$ \\
\hline 3. & $\mathrm{Hm} .7$ & Xenotime, tapiolite, goethite, uvanite & Ferruginous sandstone at $\mathrm{G}$. Hemeyyir locality. & $29^{\circ} 01^{\prime} 30^{\prime \prime} \mathrm{N}$ & $33^{\circ} 32^{2} 37^{7{ }^{7} \mathrm{E}}$ \\
\hline 4. & Hm.5 & Xenotime, wanite, magnentite, hemantie & $\begin{array}{l}\text { Feruguinous sundstone at G. Ghordbi locality- } \\
\text { G. Hemeyi area }\end{array}$ & $29^{\circ} 22^{\prime} 05^{\prime \prime} \mathrm{N}$ & $33^{\circ} 29^{\prime} 48^{\prime \prime} \mathrm{E}$ \\
\hline 5. & SR.1 & Zircon, xenotime, magnentile & Ferruginous sandstone at $G$. Maghara locality & $28^{\circ} 54^{\prime \prime} 37^{\prime \prime} \mathrm{N}$ & $33^{\circ} 24^{4} 16^{\prime \prime} \mathrm{E}$ \\
\hline 6. & TF.1 & Saletit, xenctime, wavellitie, quarth & $\begin{array}{l}\text { Ferruginous sandstone at } \\
\text { locality-Wa }\end{array}$ & $28^{\circ} 56^{\prime} 10^{\prime \prime} \mathrm{N}$ & $33^{\circ} 23^{\prime} 22^{\prime \prime} \mathrm{E}$ \\
\hline 7. & TF.2 & Xenotime, & $\begin{array}{l}\text { Ferruginous sandstor } \\
\text { locality }\end{array}$ & $16 \mathrm{~N}$ & $33^{\circ} 23^{\prime} 18^{\prime \prime} \mathrm{E}$ \\
\hline 8. & $\mathrm{Um} \cdot 3$ & $\begin{array}{r}\text { noime, bequereflit, hematite, } \\
\text { quartz }\end{array}$ & 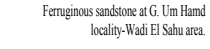 & $28^{\circ} 57^{\prime} 55^{\prime \prime} \mathrm{N}$ & $33^{\circ} 22^{2} 10^{\prime \prime} \mathrm{E}$ \\
\hline 9. & Um.4 & notime, hemanatie, euxenite, rutle & 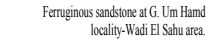 & $28^{\circ} 58^{\prime} 00^{\prime \prime} \mathrm{N}$ & $33^{\circ} 22^{\prime} 02^{\prime \prime} \mathrm{E}$ \\
\hline 10. & Um.5 & atte & $\begin{array}{l}\text { Ferruginous sandstone at G G Um Hand } \\
\text { localily-WadiEI Salu area. }\end{array}$ & $\mathrm{N}$ & 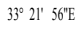 \\
\hline 11. & $\mathrm{Rm} .1$ & Florencite, airon, quartz & Basal quartrite- Araba Fm. at Ras Millan area. & $27^{\circ} 56^{4} 45^{\prime \prime} \mathrm{N}$ & $33^{\circ} 58^{\prime \prime} 52^{\prime \prime} \mathrm{E}$ \\
\hline 12. & Rm.2 & Florencite, iricon, tr. of davidite, quartz & Basal quartzite- Araba Fm at Ras Millan area. & $27^{\circ} 57^{2} 29^{\prime \prime} \mathrm{N}$ & $33^{\circ} 59^{\prime \prime} 25^{\prime \prime} \mathrm{E}$ \\
\hline 13. & $\mathrm{Rm} .3$ & $\begin{array}{l}\text { Quartz, ircon, florencite, } \\
\text { plumbogyummite }\end{array}$ & Basal quartizite-Araba Fm. at Ras Millan area. & $27^{\circ} 59^{3} 36^{\prime \prime} \mathrm{N}$ & $33^{\circ} 56^{\prime} 38^{\prime \prime E}$ \\
\hline 14. & $\mathrm{Rm} .4$ & $\begin{array}{r}\text { Quart, plumbogummitite, geethite, } \\
\text { zircon }\end{array}$ & Baxal quartizite-Ardba Fm a a Ras Millan area. & $277^{\circ} 58^{\circ} 08^{\prime \prime} \mathrm{N}$ & $33^{\circ} 58^{\prime \prime} 02^{\prime \prime} \mathrm{E}$ \\
\hline 15. & $\mathrm{Rm} .5$ & Quart, goethite, kaolinite, johannite & Basal quartizite-Araba Fm. at Ras Millan area. & $27^{\circ} 59^{111 " \mathrm{~N}}$ & $33^{\circ} 58^{\prime} 33^{\prime \prime} \mathrm{E}$ \\
\hline 16. & Rm.6 & Quart, hemantite, sodium meta-antunite & $\begin{array}{l}\text { Sandstones of top Araba Fm. at Wadi Lethi } \\
\text { locality-Ras Millan area. }\end{array}$ & $27^{\circ} 59^{30 " \mathrm{~N}}$ & $33^{\circ}$ \\
\hline 17. & $\mathrm{Rm} .7$ & leate, govazile, thoritle, izicon & 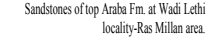 & $27^{\circ} 59^{\prime} 22^{\prime \prime}$ & \\
\hline
\end{tabular}

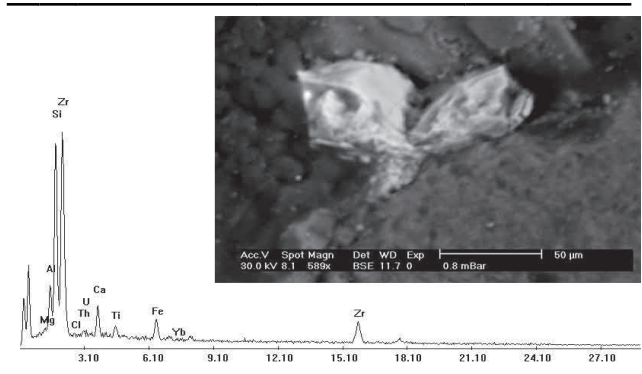

Fig.18: Back scattered SEM \& EDX of Rosy zircon grains interspaced between sand grains in thin sections

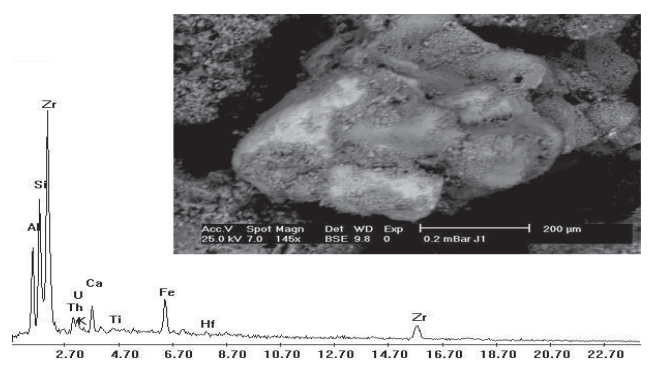

Fig.19: Back scattered SEM \& EDX of Solid solution of zircon grains cemented with Fe-Ti cement

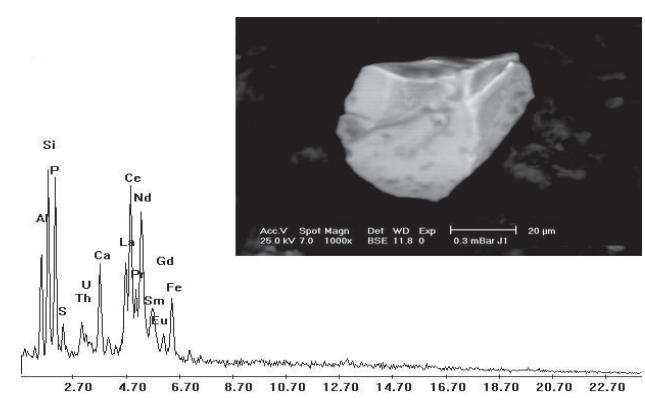

Fig. 20: Back scattered SEM \& EDX of Allanite

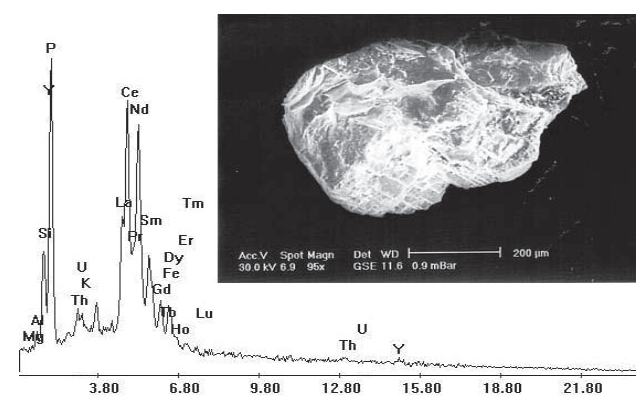

Fig.21: : Back scattered SEM \& EDX of Monazite

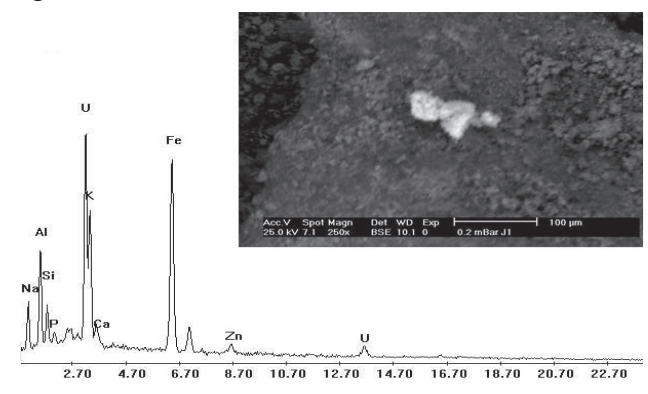

Fig.22: : Back scattered SEM \& EDX of Sodium metaautunite adsorbed on hematite

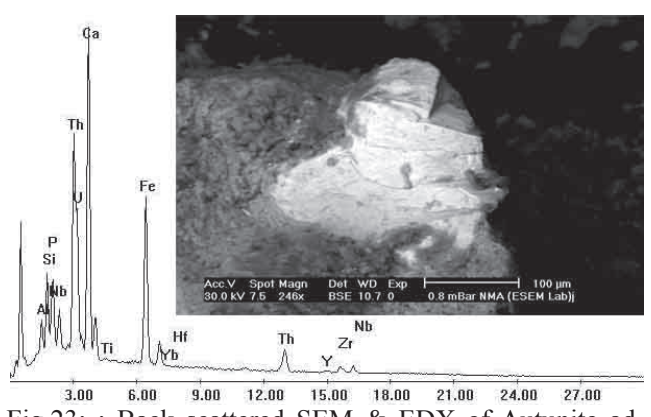

Fig.23: : Back scattered SEM \& EDX of Autunite adsorbed on ilmenorutile 


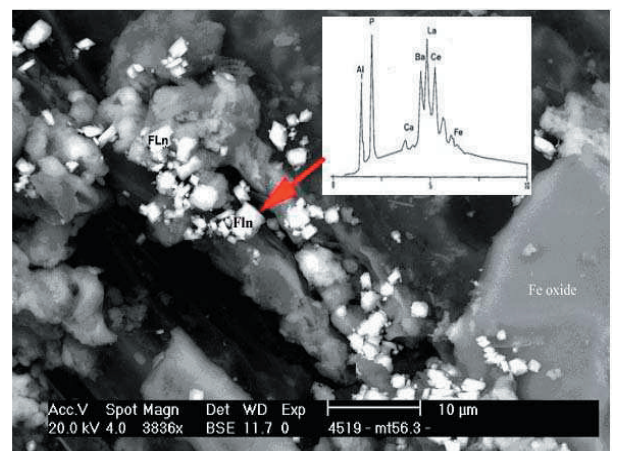

Fig.24: : Back scattered SEM \& EDX of Florencite (Fln)

The radioactive sandstones of Abu Thora Formation are controlled mainly by the presence of uraniferous detrital grains. The high $U$ content may be attributed to its presence of some refractory minerals as sphene $\mathrm{CaTiSiO}_{5}$ (Fig.25), columbite $\mathrm{FeNb}_{2} \mathrm{O}_{6}$ (Fig.26), apatite (Fig.27), zircon, and monazite (as detected from petrographic study). The leachable uranium hosted in the interbedded mudstones and siltstones is captured by the dominant iron oxides, clay minerals and organic matter dominant in these lithofacies. Also, $\mathrm{U}$ occurs in spots within other minerals as graphite C (Fig.28) and may be adsorbed by clay minerals (mainly kaolinite $\left.\mathrm{Al}_{2} \mathrm{Si}_{2} \mathrm{O}_{5} \cdot(\mathrm{OH})_{4}\right)$.

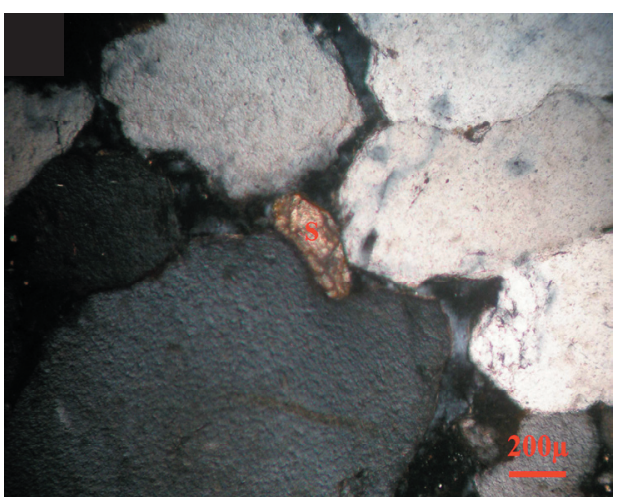

Fig. 25: Quartz arenite contains interspaces sphene (S) grains, $\mathrm{xpl}$

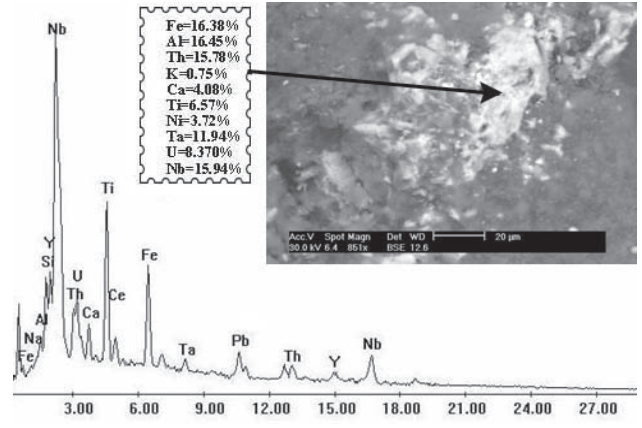

Fig.26: EDX and SEM of columbite inclusions (pointed by arrow) within felsic rock fragment

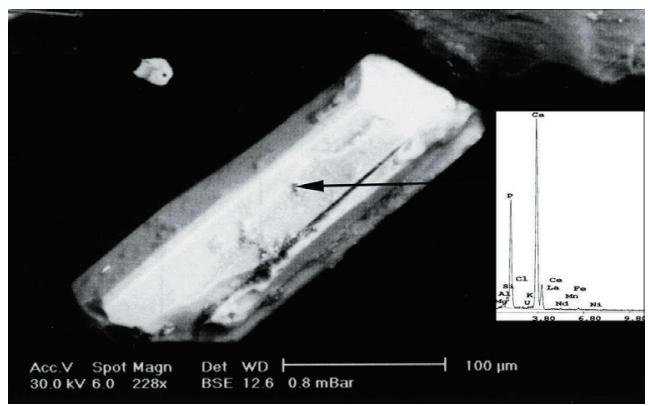

Fig.27: EDX and SEM of apatite

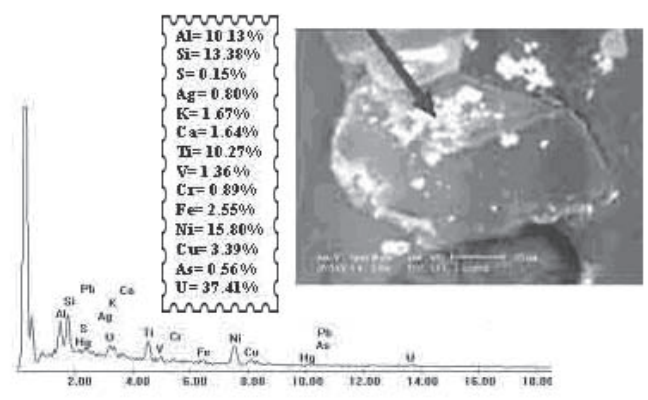

Fig.28: : EDX and SEM of graphite grains

\section{GEOCHEMISTRY}

Forty-one samples are chemically analyzed for their major and trace elements (Table 8).

The Whole Rock Geochemistry of the UBearing Sandstones

The averages of elemental concentrations of the studied sandstones are normalized to the upper continental crust (UCC) of Taylor 
and McLennan (1985) as given in Table (8). The normalization shows that the studied sandstones are significantly depleted in $\mathrm{Al}_{2} \mathrm{O}_{3}$, $\mathrm{TiO}_{2}, \mathrm{MgO}, \mathrm{Na}_{2} \mathrm{O}, \mathrm{K}_{2} \mathrm{O}, \mathrm{Ba}$ and $\mathrm{Rb}$ relative to its concentrations in the Upper Continental Crust (UCC). The studied sandstones are significantly enriched in $\mathrm{Fe}_{2} \mathrm{O}_{3}, \mathrm{P}_{2} \mathrm{O}_{5}, \mathrm{Nb}, \mathrm{Zr}, \mathrm{Y}$, $\mathrm{Sr}, \mathrm{Ni}, \mathrm{Cr}, \mathrm{Zn}, \mathrm{Pb}, \mathrm{V}, \mathrm{U}$ and Th. Whereas the basal conglomerate lenses are depleted in $\mathrm{Zr}$, $\mathrm{Ni}, \mathrm{V}$ and $\mathrm{Y}$ relative to other studied clastics. They are enriched in $\mathrm{Ba}$ indicating the near granitic source rocks for this basal lithofacies. The average $\mathrm{SiO}_{2}$ and $\mathrm{CaO}$ contents in the studied sandstones are close to its average concentrations in the Upper Continental Crust (UCC). These could be attributed to the dilution by the $\mathrm{Fe}_{2} \mathrm{O}_{3}$ as well as clay minerals $\left(\mathrm{Al}_{2} \mathrm{O}_{3}\right)$. The enrichment in $\mathrm{Al}_{2} \mathrm{O}_{3}$ and the depletion in $\mathrm{K}_{2} \mathrm{O}$ and $\mathrm{SiO}_{2}$ mean that kaolinite is the main mineral in the clay admixture (confirmed by XRD data; see mineralogy section). The lower concentration of $\mathrm{Rb}$ in the studied sandstones is attributed to the depletion of $\mathrm{K}_{2} \mathrm{O}$ (where $\mathrm{Rb}$ is geochemically related to $\mathrm{K}^{2}$ in clay minerals). The enrichment of $\mathrm{P}_{2} \mathrm{O}_{5}, \mathrm{Al}_{2} \mathrm{O}_{3}$, $\mathrm{Fe}_{2} \mathrm{O}_{3}, \mathrm{Zr}, \mathrm{Y}, \mathrm{Sr}, \mathrm{Ni}, \mathrm{Cr}, \mathrm{Zn}, \mathrm{Pb}, \mathrm{Ba}^{2}, \mathrm{~V}, \mathrm{U}$ and Th may be attributed to the high content of zircon, iron oxyhydroxides, phosphate minerals (either uranium or aluminium phosphates) and iron titanium detrital minerals. $\mathrm{Zn}, \mathrm{Ni}, \mathrm{Fe}_{2} \mathrm{O}_{3}$ are highly enriched in the studied ferruginous sandstones (top El Adedia Formation) relative to the Upper Continental Crust (UCC). This can be attributed to adsorption of both $\mathrm{Zn}$ and $\mathrm{Ni}$ on colloidal iron oxy-hydroxides as well as coatings on the framework quartz grains (Figs.13\&14). This is in agreement with the conclusion of Wedepohl (1972) and Levinson (1980). ZnO was detected with SEM investigations as mineral phase dominant in the studied radioactive ferruginous sandstones.

The chemical analyses of El Adedia sandstones samples show that $\mathrm{Al}_{2} \mathrm{O}_{3}$ contents reach up to $15.97 \%$. The higher values are attributed to the presence of clay minerals (kaolinite) and secondary aluminum phosphate minerals (goyazite, florencite, plumbogummite, wavellite, vivianite). $\mathrm{Fe}_{2} \mathrm{O}_{3} \%$ ranges from $0.52 \%$ in the non anomalous white sandstones to 30.9 $\%$ in the ferruginous lateritic siltstones. The
Table 8: Average chemical composition of the studied Paleozoic sandstones and representative samples from the promising localities, southwest Sinai

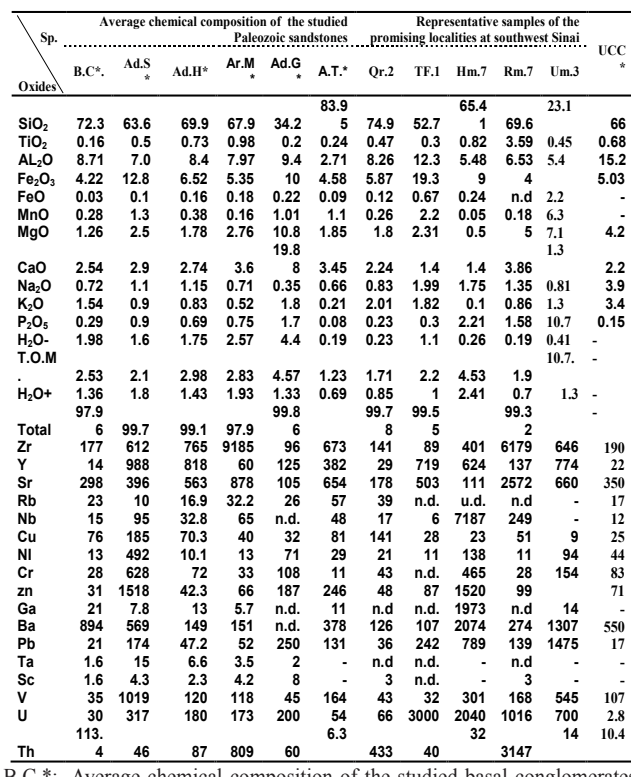

B.C.*: Average chemical composition of the studied basal conglomerates Ad.S*: Average chemical composition of the ferruginous S.S. at Wadi E Sahu area; Ad.H*: Average chemical composition of the ferruginous S.S at Gabal Hemeyir area;Ar.M*: Average chemical composition of the Araba sandstones at Ras Millan area;Ad.G*: Average chemical composition of the ferruginous S.S. at Gabal Maghara locality; A.T.*: Average chemical composition of the Abu Thora Formation; UCC*: Average che
Upper Continental Crust (Taylor and McLennan; 1985)

higher $\mathrm{Fe}_{2} \mathrm{O}_{3}$ values were recorded in the ferruginous pebbly sandstones, sandstones and lateritic siltstones, as a result of the dominance of iron oxhydroxides as secondary components and cementing materials. $\mathrm{CaO}$ contents vary from $0.5 \%$ to $6.68 \%(1.68 \%$ in average). $\mathrm{P}_{2} \mathrm{O}_{5}$ contents range from 0.23 $\%$ to $6.4 \%$ (1.86 \% in average), its highest contents are in the ferruginous pebbly sandstones, lateritic siltstones and Araba sandstone due to the dominance of xenotime, apatite and other secondary Al-phosphate minerals. $\mathrm{Na}_{2} \mathrm{O}, \mathrm{K}_{2} \mathrm{O}$ and $\mathrm{MgO}$ contents are usually depleted in the studied clastics because they are extremely mobile and are usually leached out during chemical weathering. The highest concentrations of $\mathrm{TiO}_{2}$ (reach up to $3.37 \%$ ) was attributed mostly to the presence of ilmenite, rutile and anatase minerals being identified by $\mathrm{XRD}$ as well as SEM and EDS investigations 
for the studied sandstones. Y contents range from $11 \mathrm{ppm}$ to $4585 \mathrm{ppm}$. The higher contents were recorded in the ferruginous pebbly sandstones and lateritic siltstones supporting the presence of xenotime, fergusonite, monazite and allanite minerals. $\mathrm{Zr}$ is considered the most dominant trace element in the studied sandstones. It is highly concentrated in the Abu Thora white sandstone (reach up to $766 \mathrm{ppm}$ ), El Adedia ferruginous sandstones (reach up to $21156 \mathrm{ppm}$ ) and Araba sandstones (reach up to $10.6 \%$ ) as a result of the presence of detrital zircon grains. It is dominant mainly in the black sand placers as well as dispersed in the matrix of the studied sandstones. Vanadium occurs in relatively high concentrations in both the ferruginous sandstones and lateritic siltstones (V reaches up to $1115 \mathrm{ppm}$ ). The high vanadium content is attributed to the presence of secondary uranium vanadate mineral; uvanite as well as detrital ilmenite and magnetite minerals which are dominant in the ferruginous sandstones and paleoplacers. The source of vanadium is not known, but at least two possibilities have been presented. Vanadium may have been derived from (a) the breakdown of detrital magnetite and ilmenite within the host sediments or (b) liberated by chemical weathering of accessory minerals within the source area. Ba and $\mathrm{Sr}$ have moderate to high contents confirming their near acidic source rocks of the studied lithofacies (mainly El Adedia Formation and basal conglomerate lenses).

The most important geochemical characteristics of the studied sandstones are the high concentrations of Ga and W (reach up to 1973 ppm and 314 ppm, respectively) in the ferruginous sandstones of Gabal Hemeyir area and the high concentration of Sn and $\mathrm{W}$ in the basal quartzite of Araba Formation at Ras Millan area (reach up to 1064 ppm and 216 ppm respectively). Gallium is related to the dominance of aluminium bearing mineral phases either the clay minerals or the Al-phosphate minerals. While $\mathrm{Sn}^{4+}$ and $\mathrm{W}^{6+}$ are geochemically coherent elements and incorporated in accessory mineral phases and mica persist as complexes in late stage and post magmatic hydrous fluids and are deposited in quartz veins and the greisens borders of the granitic plutons. It seems probable, that these elements were associated with $\mathrm{U}^{6+}$ scoured from the granitic country rocks in the studied basins by circulation of hydrothermal and/or meteoric fluids and are concentrated during lateritization processes.

The different lithofacies of Abu Thora Formation show a wide span range in its chemical composition (Table 8 ). The maximum concentration of $\mathrm{SiO}_{2}(91.75 \%)$ was in the milky white sandstones lithofacies (exploited for glass sand) at Ras Nukhul, Bedaa (WNW G. Um Rinna; Fig.8) and El Khaboba localities. Such high silica content is attributed to the detrital quartz grains. While the radioactive varicoloured siltstones and claystones show the lowest silica contents $(11.6 \%)$ and have the maximum contents in $\mathrm{Al}_{2} \mathrm{O}_{3}, \mathrm{MgO}$, $\mathrm{CaO}, \mathrm{P}_{2} \mathrm{O}_{5}, \mathrm{Ni}, \mathrm{Y}, \mathrm{Co}$ and $\mathrm{Ga}$. The increasing of $\mathrm{Al}_{2} \mathrm{O}_{3}$ and decreasing in silica contents are attributed to feldspars breakdown and silica mobilization during the alteration and dissolution of the main framework grains. These alteration processes led to liberation of magnesium from the underlying dolostones of Um Bogma Formation and its re-precipitation in the overlying clastics as cement materials (petrographically detected as dolomite; El Afandy et al., 2010). The positive correlation between $\mathrm{P}_{2} \mathrm{O}_{5}$ and each of $\mathrm{Y}, \mathrm{V}$ and $\mathrm{Nb}$ is attributed to the presence of tiny monazite grains included in the framework granitic rock fragments and quartz grains ( petrographic investigation; El Afandy et al., Op. Cit.).

\section{REE Patterns of the Paleozoic U-Bearing Sandstones in Southwest Sinai}

The studied sandstones contain huge amount of the most REE accumulators as monazite, xenotime, allanite . So, these sandstones enriched in rare earth elements whereas $\sum$ REE budget reach up to $8035.4 \mathrm{ppm}$. The chondrite normalized REE patterns (Fig.29a) show that these sandstones are enriched in 

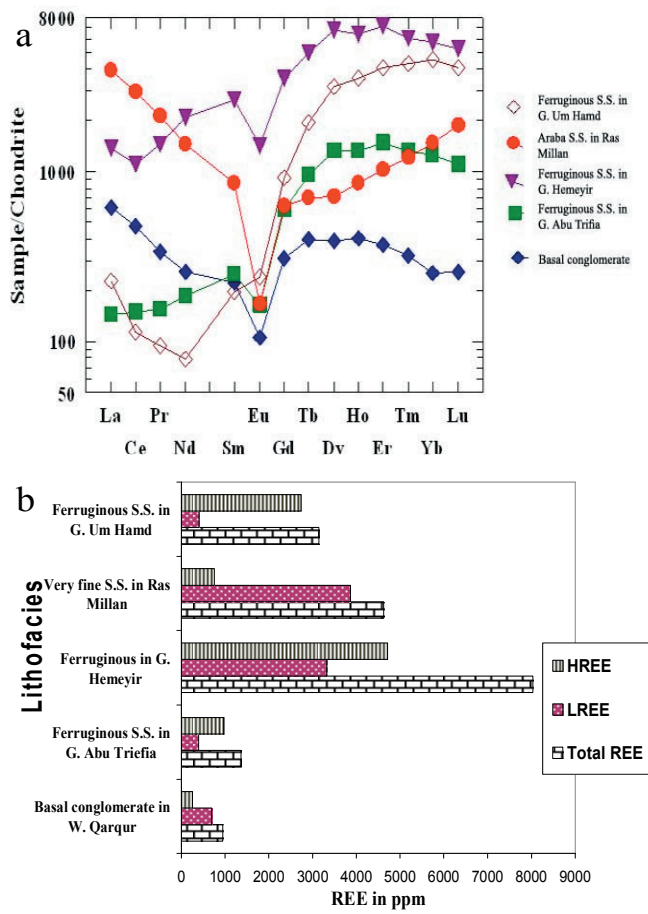

Fig.29: Chondrite-normalized REE patterns (a) and histograms show the REE concentrations (b) of representative samples from the studied sandstones in promising localities at southwest Sinai

HREE and LREE and diagnostically deficit in $\mathrm{Eu}$ due to the breakdown of plagioclase and orthoclase. It shows a negative Eu anomaly ($\Delta$ Eu ranges from 0.23 to 0.55 ; Table 9). The strong negative $-\Delta \mathrm{Eu}$ anomaly in the studied conglomerates and sandstones can be attributed to the source rocks which are composed mainly of highly differentiated granite (depleted in Eu). Moreover the present stream placers are highly winnowed and sorted causing the alteration and losting most of plagioclases (improves the depletion in Eu). The chondrite normalized REE patterns show sudden drop concave toward MREE ( $\mathrm{Sm}, \mathrm{Eu}$ and $\mathrm{Gd}$ ) and shows linear increase toward both LREE and HREE (Fig. 29a). Table (9) shows the contents and averages of the REE. The most abundant rare earth elements in these sandstones are Ce, La, Nd, Yb, Dy, Er, Gd, Pr, Sm, and Ho.
Whereas the lowest concentration correspond $\mathrm{Eu}, \mathrm{Tm}, \mathrm{Tb}$ and $\mathrm{Lu}$. The LREE/HREE ratios vary from 0.15 to 5.2 . This attributed to enrichment in both LREE (the basal conglomerate at Wadi Qarqur, the ferruginous sandstone in Gabal Hemeyir and the very fine sandstone in Ras Millan area) and HREE (the ferruginous sandstones in Gabal Abu Triefia, Gabal Hemeyir and Gabal Um Hamd) (Fig.29b). The high LREE content attributed to the dominance of the detrital monazite, davidite, allanite and secondary Al- phosphate minerals which are enriched in LREE (as goyazite and florencite). The LREE fractionation confirmed by the positive $\mathrm{Ce}$ anomaly $+\Delta \mathrm{Ce}\left(\mathrm{Ce} / \mathrm{Ce}^{*}\right.$ $1.08 \& 1.1$; Table 9) and the high $\mathrm{La} / \mathrm{Yb}_{\mathrm{n}}$ ratios as well as the EDS data of the separated allanite, monazite, davidite and florencite grains (Figs.20-22). Generally, the LREE especially $\mathrm{Ce}, \mathrm{La}$ and $\mathrm{Nd}$ are more mobilized during the hydrothermal alteration and weathering processes (Nesbitt, 1979; Giere, 1996). Whereas the HREE enrichment in the studied sandstones is mainly attributed to the dominance of xenotime, allanite, fergusonite and zircon. The HREE fractionation ( $\mathrm{Yb}$ reaches up to 985.3 ppm, Dy up to 1714 ppm, Er up to 1178 ppm and Ho up to $362.9 \mathrm{ppm}$ ) in the ferruginous

Table 9:Rare earth elements concentrations and geochemical ratios of the representative samples from the Paleozoic sandstones, southwest Sinai.

\begin{tabular}{|c|c|c|c|c|c|}
\hline Element & Qr2 & TF.1 & Hm.7 & Rm.7 & Um.3 \\
\hline $\mathbf{L a}$ & 147 & 34.3 & 327 & 929 & 54 \\
\hline $\mathrm{Ce}$ & 290 & 91.9 & 678.4 & 1800 & 70 \\
\hline $\mathbf{P r}$ & 32 & 14.6 & 137.5 & 200 & 9 \\
\hline Nd & 120 & 86.6 & 970.5 & 670 & 37 \\
\hline Sm & 34 & 38.3 & 400.1 & 130 & 32 \\
\hline Eu & 6.1 & 9.5 & 81.9 & 9.6 & 14 \\
\hline Gd & 64 & 122.8 & 724.8 & 130 & 188 \\
\hline Tb & 15 & 35.8 & 185.9 & 26 & 73 \\
\hline Dy & 100 & 337.8 & 1714 & 180 & 804 \\
\hline Ho & 23 & 74.7 & 362.9 & 48 & 200 \\
\hline Er & 61 & 243.6 & 1178 & 170 & 679 \\
\hline $\mathbf{T m}$ & 8.2 & 33.5 & 155.2 & 31 & 110 \\
\hline $\mathbf{Y b}$ & 43 & 214.4 & 985.3 & 250 & 769 \\
\hline Lu & 6.5 & 28.2 & 133.9 & 47 & 103 \\
\hline$\sum$ REE & 949.8 & 1366 & 0 & 6 & 3142 \\
\hline LREE & 693.1 & 398 & 3320.2 & 368.8 & 404 \\
\hline HREE & 256.7 & 968 & 4715.2 & 752 & 2738 \\
\hline & 0.4 & 0.42 & 0.46 & 0.23 & 0.55 \\
\hline$E$ & 2.7 & 0.4 & 0 & 5.2 & 0.15 \\
\hline CelC & 1.03 & 0.96 & 0.7 & 1.1 & 0.71 \\
\hline $\mathrm{a} / \mathrm{Ybn}$ & 2.45 & 0.12 & 0.24 & 2.67 & 0.008 \\
\hline
\end{tabular}


sandstones lithofacies may be attributed to the supergene and lateritization processes located in the topmost part of El Adedia and Araba formations.

\section{REE and U Mobilization Within the Fault Zones of the Paleozoic Sandstones}

The LREE, HREE and U were mobilized to a significant distance and incorporated within separated mineral phases by the high P-rich fluid. The role of the P-rich fluids in the alteration and mobilization processes for both REE and $U$ can be predicted from the dominance of secondary Al-phosphate minerals as goyazite, florencite, wavellite, vivianite, plumbogummite and U-phosphate minerals; threadgoldite, saleeite, sodium met-autunite in the studied sandstones. The source of the Pbearing meteoric fluids may be from the dissolution of primary apatite (Pagel, 1984) existing in the nearby basement granitoid rocks and hosted as detrital phase in these sandstones. The deeply penetrated heated meteoric water (in fractured sandstones) release $\mathrm{U}$ and REE from the present accessory minerals such as monazite, apatite, allanite, zircon and xenotime. U and REE-bearing solution transports through the pre-existing faults and permeable braided channels. Retention of uranium from a solution carried out by clay minerals, iron oxides and organic matter through sorption. The negative Ce anomaly confirms the effect of oxic groundwater in Ce fractionation and its precipitation as Ce (IV) oxide (Jerden and Sinha, 2003). Hidaka et al. (2005) attributed the large chemical fractionation between $\mathrm{Ce}$ and other LREE to the formation of secondary minerals under oxidizing conditions. The presence of secondary uranium mineralization postulates high alkaline, meteoric nature and relatively low temperature for these solutions. The role of groundwater in the distribution of secondary uranium mineralization occurs when circulation of meteoric water could penetrate to deeper granitic parts along faults and fracture zones. When the fluids approach the surface, passing through fracture system, the pressure decreased and the $\mathrm{pH}$ increased due to the loss of volatile components (Romberger, 1984). They become alkaline and oxidizing and causes subsolidus alterations processes. Evidences of the alkaline and oxidizing nature of the ascending fluids in the studied sandstones include: (1) dissolution of quartz, (2) enrichment of the altered clastics in $\mathrm{Ca}, \mathrm{Mg}$ and precipitation of iron as oxyhydroxides, (3) precipitation of secondary uranium phases, (4) hematization and pseudomorphic oxidation of pyrite to limonite and goethite.

METALLOGENIC ASPECTS OF THE STUDIED SANDSTONE-TYPE URANIUM DEPOSITS AT SOUTHWEST SINAI

The studied Paleozoic sandstones at southwest Sinai host two types of uranium mineralization:

\section{The Syngenetic Continental/Littoral Paleoplacers}

This type of mineralization includes mainly refractory minerals detrital from nearby and/or far distant source rocks. They are hosted in two different stratigraphic horizons. The first placers are those in the basal polymictic conglomerate lenses in Gabal Adedia, Wadi Qarqur, Wadi Main and Gabal Nukhul. The second placers are those of black sand lenses exist in the sandstones of El Adedia Formation (common in Um Bogma area; Wadi El Seih, Abu Hamata, Gabal Sad El Banat, Ras El Homira and in Gabal Hemeyir area; Gabal Ghorabi) and topmost part of Araba Formation in Ras Millan area. The detrital Th-U bearing minerals were transported and concentrated by repeated recycling and mechanical sorting within a high energy surface hydrologic environment. The close association of these placers with regional unconformities documents the importance of erosion and sediment recycling in the concentration processes. Mineralization exists mainly in typical sedimentary characteristics of braided stream depositional systems with extremely coarse sediment size, normal grading vertical sequence, and maxi- 
mum ratio of channel width to thickness and limited flood plain size. The mineralized sandy braided channels are comparatively smaller, and their most common sedimentary structure is large-scale trough cross-bedding.

Two types of placers can be recognized on the basis of depositional environment as stream and beach. Stream placers occur in the high energy ephemeral deposits formed close to their source area (mainly recorded in basal conglomerates). Beach (littoral) placers that formed either as beaches or various types of bars (longshore, baymouth, shoal ..etc) which recorded mainly in black sand lenses. Both stream and beach paleoplacers are common in the studied Paleozoic sandstones. Meander loops and channels with deep scours appear to be the most favourable sites for this mineralization.

\section{The Epigenetic Tectolithologic-Type Sandstone Uranium Deposits}

These epigenetic uranium deposits hosted in the sandstones unconformably overlying the Precambrian basement rocks or faulted against them such as the ferruginous sandstones in the topmost parts of El Adedia and Araba formations, and the fault controlled sandstone blocks of Abu Thora Formation. The tectonic history of southern Sinai is considered to be one of the most important factors in the formation of this sandstone-type uranium deposits. Since the gradual uplift of the region in early Mesozoic time and the development of extensional tectonism, were probably responsible for extensive block faulting and formation of major fault lines (NW-SE fault sets appear to be closely associated with the described mineralization). The open structure of the studied sedimentary basins, with its well-developed interconnecting high-angle normal fault and fracture systems is capable of sustaining a well-developed regional groundwater flow. The groundwater is bicarbonated, highly uraniferous ( $>50 \mathrm{ppb}$; Shata, 1997), phosphate rich and structurally controlled. This groundwater type results in various processes of dissolution, leaching, alteration, remobilization and mineralization. The fining-upward sequence of fluvial sediments (host to mineralization) act either as aquicludes or aquitards to groundwater flow, channelling uraniferous waters into the more pervious sandstones and conglomerates along fault zones. So, the recorded uranium mineralization is seldom to occur far from fault zones and is stacked up at different horizons along the fault lines. The radioactive anomalies in these sandstones show a wide variation in their intensities due to mineralogical composition, secondary alteration and/or due to diagenetic features. The uraniferous fluids enter oxidizing environment along the permeating fault zones which contain oxides or clay minerals capable of adsorbing uranium from solutions. The ferric hydroxide is a very effective scavenger of metals including U (Langmuir, 1978) from these fluids. The sorption of $U^{6+}$ onto Fe oxyhydroxides and organic matter is carried out over a wide range of $\mathrm{pH}$ conditions (Hsi and Langmiur, 1985; Moyes et al., 2000). Petrographic studies show that the studied sandstones contain a considerable granitic and volcanic rock fragments. During the supergene alteration processes, the trace content of uranium in these rock fragments would be oxidized to the hexavalent state $\left(\mathrm{U}^{6+}\right)$ and taken into solution. The flow of mineralized fluids through the host rock is responsible for the deposition of this epigenetic mineralization which classified as epigenetic tecto-lithologic or post fault type according to Young (1964).

The depositional successions which host to the present epigenetic $U$ mineralization comprise three parts; fine sediments at the bottom, coarse sediments in the middle and fine sediments at the top, which can serve as confining beds. In this trap the uranium mineralization extend in linguoid shapes in rich sand braided channels and the ore bodies mainly lay in the front of interlayer oxidized zones. The present epigenetic mineralization exists as secondary uranium phosphate minerals which result from dissolution and remobilization of uranium 
from primary apatite (Pagel, 1984). SEM investigation shows irregular form of the present xenotime mineral grains (Fig.17) confirming the probable secondary origin of this mineral. The second form of epigenetic mineralization exists as U-Ti bearing grains and cement materials associated to ilmenite and altered rutile (Fig.23). They were apparently formed from the liberated $\mathrm{Ti}$ and $\mathrm{U}$ ions from the distortion of zircon, sphene and monazite during alteration of these minerals. Some oxidized titanium compounds formed either by leucoxenation of clastic minerals (ilmenite) or precipitated from solutions in the course of cementation and belong to certain uranium collectors. All of these leucoxenes are composed of rutile and anatase with an admixture of $\mathrm{TiO}_{2} \cdot \mathrm{nH}_{2} \mathrm{O}$ gel. There is a certain convergence between the clastic Tibearing minerals alteration and the processes resulting in generation and recrystallization of $\mathrm{TiO}_{2}$-gels (Cuney et al., 1991).

\section{CONCLUSIONS}

The Paleozoic sandstones host two types of uranium mineralization. The first is the syngenetic continental/littoral paleoplacers consists of refractory Th-U bearing minerals which were detritus from distant and/or nearby source rocks. Meander loops and channels with deep scours appear to be the most favourable sites for these paleoplacers. The second is the tectonic-lithologic sandstone-type uranium deposits, which formed by epigenetic U-enrichment within the sandstones along the permeable fault zones. The tectonic-lithologic stack type deposits are in part considered the product of uranium redistribution, released from the lattice of the refractory minerals into permeable hosts along structure lines take place by younger tectonic processes. The epigenetic uranium deposits stacked up through successive horizons of the faulted CambroOrdovician and lower Carboniferous clastics in southwest Sinai. The radioactive anomalies in these sandstones related mainly to mineralogic composition, secondary alteration and/or due to diagenetic features which control this type of mineralization. The low temperature ore-forming groundwaters were slightly bicarbonate, highly uraniferous and phosphorusbearing moved along interconnecting faults and fracture zones into the fabric-loosened body of braided depositional systems. The tectonic history of southern Sinai is considered to be one of the most important factors in the formation of this sandstone-type uranium deposits. The U-bearing refractory minerals in the oxidization environments liberate the uranyl ion which is somewhat mobile in weakly acid solutions in the porous and permeable braided channels along the extensive faulted blocks and major fault zones.

The present uranium and thorium bearing minerals hosted in the investigated sandstones are mainly chemical compounds of phosphates, vanadates and titanium oxides. The clay minerals, iron oxides and organic matter play vital role in the fixation of mobile uranium along the permeable fault zones. Most of $\mathrm{Zn}, \mathrm{Ni}, \mathrm{Cr}, \mathrm{U}$, and $\mathrm{V}$ are mainly adsorbed on colloidal iron hydroxides cement materials. The enrichment of $\mathrm{Zr}$, Y, Th, $\mathrm{Pb}$ and $\mathrm{Nb}$ attributed to presence of detrital refractory minerals. The $\mathrm{TiO}_{2}$ content of the present sandstone not fully explained in terms of detrital but also secondary enrichment by $\mathrm{TiO}_{2}$ retention on the clay fraction. The cement materials include titanium oxides (anatase) and iron oxyhydroxides play essential role in the fixation of the mobilized uranyl ions.

The tectonic-lithologic type uranium deposits occurring in significant quantities in the ferruginous sandstones of El Adedia Formation at Gabal Hemeyir, Wadi El Sahu and Gabal Maghara areas as well as the equivalent clastics of Araba Formation at Ras Millan area. The wide aerial extension of these promising sandstones moreover enrichment in REE, Ga, $\mathrm{Sn}$ and $\mathrm{W}$ increase the economic significance of these U-resources in southwest Sinai. So, the promising localities need to further exploration in detail. 


\section{REFERENCES}

Abdel Monem, A.A.; Hashad, A.H.; El Kiki,M.F., 1958. The radioactive exploration and the radioactivity of West Central Sinai. Unpublished report, U.A.R. A., Atomic Energy Establishment, Cairo, Egypt.

Adams, J.A.S., and Weaver, C.E., 1958. Thorium to uranium ratios as indicator for sedimentary processes; an example of geochemical facies. Am. Assoc. Pet. Geol. Bull., 42, 397-430.

Afifi, S.Y.,1991.Geochemical investigation of some radioactive Lower Carboniferous sedimentary rocks of Wadi Nasieb area, west central Sinai, Egypt. M. Sc. Thesis, Suez Canal Univ., Egypt. $253 \mathrm{p}$.

Akarish, A.I., and El Gohary, A.M., 2008. Petrography and geochemistry of lower Paleozoic sandstones, East Sinai, Egypt: Implications for provenance and tectonic setting. J. Afri. Earth Sci., 52, 43-54.

Ball, J., 1916. The geography and geology of west central Sinai, Egypt. Surv. Dept., Cairo, 21p.

Cant,D.J.,1978. Development of a facies model for sandy braided river sedimentation, comparison of the South Saskatechewan River and the Battery point Formation. In: Fluvial Sedimentology (Miall ,A. D.,ed). Can. Soc. Pet. Geol. Mem. No. 5, 627-641.

Cuney, M.; VonPechmann, E.; Rimsaite, J.; Simova, F.; Sorensen, H.; Augustithis, S. S., 1991. Primary radioactive minerals; The textural patterns of radioactive mineral paragenetic associations. Theophrastus Publi., S. A. Zographou, Athens, Greece, 417p.

Dahlkamp, F.J., 1978. Classification of uranium deposits. Mineralium Deposita, 13, 83-104.

El Aassy, I.E.; Botros, N.H.; Abdel Raziq, A.; Sherif, H.; Al Moafy, A.; Atia, K.; EL Terb, R.; Al Shami, A., 1986. Report on the prospection and proving of some radioactive occurrences in West Central Sinai, Egypt. Inter. Report, NMA ,Cairo.
El Afandy, A. H.; Shata A. E.; Abd El Halim, K. A., 2010. Geochemistry and radioactivity of Abu Thora Formation Southwest Sinai, Egypt. Sci. J. Fac. Sci. Minufiya Univ., XXIV, 31-69.

El Agami, N. L., 1996. Geology and radioactivity studies on the Paleozoic rock units in the Sinai Peninsula, Egypt. Ph.D. Thesis, Mansoura Univ., Egypt, 302 p.

El Beleity, A.; Ghoneim, M.; Hinawi, M.; Fathi, M.; Gebali, H.; Kamel, M., 1986. Palaeozoic stratigraphy, paleogeography and paleotectonics in the Gulf of Suez. E.G.P.C: $8^{\text {th }}$ Exploration Conf., Cairo, 21 p.

El Kammar, A. M.; El Aassy, I. M., and Abram, F. B., 1997. Rare earth elements and crystal chemistry of xenotime bearing sediments of Um Bogma area, Southwestern Sinai, Egypt. Chem. der Erde, 57/1, 91-101.

El Sokkary, A. A., 1971. Radiogeologic studies of some Carboniferous rocks, west central Sinai; J. Geol. U.A.R., 15(2), 119-127.

Finch, W. I., 1967. Geology of epigenetic uranium deposits in sandstones in the United States. U.S. Geol. Surv., Professional Paper 538, 121.

Galloway, W. E., 1979. Early Tertiary-Wyoming intermontane basin. In: Depositional and GroundWater Flow Systems in the Exploration for Uranium. Austin, Texas, Texas Univ., Bureau of Economic Geology, 197-213.

Giere', R., 1996. Formation of rare earth elements in hydrothermal systems.In: Rare Earth Minerals, chemistry, origin and ore deposits (Jones, A.P. ;Walls, F.; Williams C.T., eds). Mineral. Soc. Ser., 7, 105-150.

Hassan, A.A., 1967. A new Carboniferous occurrence in Abu Durba, Sinai, Egypt. $6^{\text {th }}$ Arab Petrol. Cong., Baghdad, 2, 8p.

Hidaka, H.; Janeczek, J.; Skomurski, F.N.; Ewing, R.; Gauthier-Lafaye, F., 2005. Geochemical fixation of rare earth elements into secondary minerals in sandstones beneath a natural fission reactor at Bangombé, Gabon. Geochim. Cosmo. Acta, 69(3), 685-694. 
Hobday, D.K., and Galloway, W.E., 1999. Groundwater processes and sedimentary uranium deposits. Hydrogeol. J., 7, 127-138.

Hsi, C.K., and Langmuir, D., 1985. Adsorption of uranyl onto ferric oxyhydroxides, Application of the surface complexation site binding mode. Geochim. Cosmo. Acta, 19, 1931-1941.

IAEA, 1996. Guidebook to Accompany IAEA Map; World Distribution of Uranium Deposits. Inter. Atomic Energy Agency, Vienna.

Issawi, B.; El-Hinnawi, N.; Khawaga, L.; Labib, S.; Anani, N., 1981. Contributions to the geology of Wadi Feiran area, Sinai, Egypt. Petrobel Report, $48 \mathrm{p}$.

Issawi, B., and Jux, U., 1982. Contributions to the stratigraphy of the Palaeozoic rocks in Egypt. Geol. Surv. Egypt, paper 64, 1-28.

Klitzsch, E., 1990. Palaeozoic. In: The Geology of Egypt (Said, R., ed.). Balkama, Rotterdam, 393-406

Kora, M., 1984. The Palaeozoic outcrops of Um Bogma area, Sinai. Ph.D. Thesis, Mansoura Univ., Egypt, 280p.

Langmuir, D., 1978. Uranium solution-mineral equilibria at low temperatures with applications to sedimentary ore deposits. Geochim. Cosmo. Acta 42, 547- 556.

Levinson, A. A. 1980. Introduction to exploration geochemistry. Dept. geol. and geophysics, Calgary Univ., Calgary, Alberta. Canada, Applied publishing Ltd., Wilmette, Illinois, 601p.

Jerden, J. L. Jr., and Sinha, A. K., 2003. Phosphate based immobilization of uranium in an oxidizing bedrock aquifer, Appl. Geochemist. J., 18(6), 823-843.

Moyes, L. N.; Parkman, R. H.; Charnock, J. M.; Vaughan, D. J.; Livens, F. R;Hughes, C. R. Braithwaite, A., 2000. Uranium uptake from aqueous solution by interaction with goethite, lepidocrosite, muscovite, and mackinawite; an-ray absorption spectroscopy study. Environ. Sci. Technol, 34, 1062-1068.

Nesbitt,H.W.,1979. Mobility and fractionation of rare-earth elements during weathering of a granodiorite. Nature, 279, 206-210.

Omara, S., 1972. An early Cambrian outcrop in southwestern Sinai, Egypt. Neues Jahrbuch fur Geologie und Pala "ontologie Monatshefte 5, 306-314.

Pagel, M.,1984. Petrology, Mineralogy, and geochemistry of surficial uranium deposits. In: IAEA- Technical Document,322, 37-44.

Romberger, S. B., 1984. Transportation and deposition of uranium in hydrothermal systems at temperatures up to $300^{\circ} \mathrm{C}$; Geological implications. In: Uranium Geochemistry, Mineralogy, Geology, Exploration and Resources (Vivo, B.D.; Capaldi, F.I.G.; Simpson P. R.,eds.). London. Instit. Mining and Metall., 12-17.

Rust, B. R., 1972. Structure and processes in a braided river. Sedimentology 18, 221-246.

Said, R., 1971. Explanatory note to accompany the Geologic Map of Egypt. Geol. Surv. Egypt ,Paper 56, 121p.

Samaul, M.D.; Moussa, H.E.; El Gharabawi, R.E.; Ghobrial, S., 1999. Geochemistry of Mesozoic picritic and basaltic rocks of West Central Sinai, M.E.R.C., Ain Shams University. Earth Science Series, 13, 55-71.

Seilacher, A., 1990. Palaeozoic trace fossils. In: The Geology of Egypt (Said, R.,ed.). Balkama, Rotterdam, 646-670.

Shata, A. E.,1997. Geological, hydrogeological, and geochemical characteristics affecting the behavior of uranium in some rock exposures, southern Sinai, Egypt. M.Sc. Thesis,Fac. Sci., Mansoura Univ. , 186p.

Shata, A. E., 2002. Geological and geochemical studies on uranium and thorium of the selected exposures of basal sandstone in southern Sinai, Egypt. Ph. D. Thesis, Fac. Sci., Mansoura Univ. , $186 \mathrm{p}$.

Shata, A. E. 2004. Rare earth elements and uranium mobilization in the radioactive Cambro-Ordovician sandstones of Ras Millan area, south Sinai. Proc. $7^{\text {th }}$ Conf. Geol. Sinai for Develop. Ismailia, Egypt, 181-197.

Shata, A.E.; Aita, S.K.; Hosni, W.A.; El Sayed, A.A., 2011. Lithofacies and radioactivity of the Adedia Formation in Ramlet Hemeyir area, southwestern Sinai, Egypt. Sedimentology of Egypt, 19, 1-12.

Shapiro, L., and Brannnock, W. W., 1962. Rapid analysis of silicate, carbonate and phosphate 
rocks. U.S. Geol. Surv. Bull, 1114-A.

Soliman, S.M., and El Fetouh, M., 1969a. Lithostratigraphy of the Carboniferous Nubian type sandstone in west central Sinai, Egypt. VI Arab Sci. Cong., Damascuss, pt.4, 311-377.

Soliman, M.S., and EI-Fetouh, M.A., 1969b. Petrology of the Carboniferous Sandstones in West Central Sinai. J. Geol., United Arab Republic, 13, 61-143.

Taylor, S.R., and McLennan, S.M., 1985. The Continental Crust: Its Composition and Evolution. Blackwell, Oxford, 312p.

Wanas, H.A., 2011. The lower Paleozoic rock units in Egypt; An overview. Geoscience Frontiers, 2(4), 491-507.

Wedepohl, K. H., 1972. Zinc In: Handbook of geochemistry (Wedepohl, K. H., ed.). Springer, Berlin, 2, $30 \mathrm{~K} 1$ - $30 \mathrm{~K} 13$.

Weissbrod, T., 1969. The Palaeozoic of Israel and adjacent countries. Israel Geol. Surv. Bull., 47, $34 \mathrm{p}$.

World Nuclear Association (WNA), 2009. Geology of Uranium Deposits. http://world nuclear.org/ info/default.aspx?id=446>.

Young, R. G., 1964. Distribution of uranium deposits in the White Canyon-Monument Valley district, Utah-Arizona. Econ. Geol., 59, 850-873.

تمعدنات اليورانيوم الموجودة بالحجر الرملى لحقب الحياة القديمة بجنوب غرب سيناء، مصر

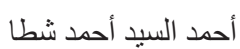

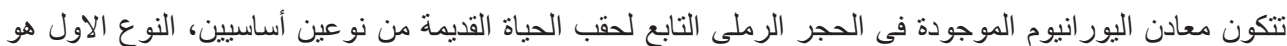

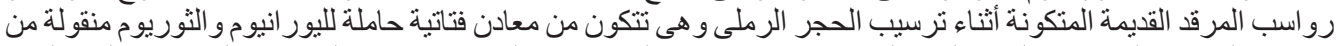

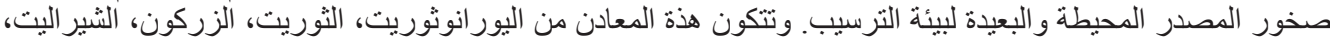

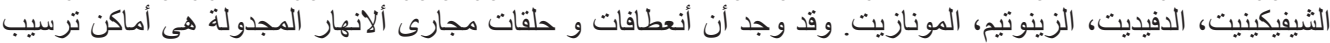

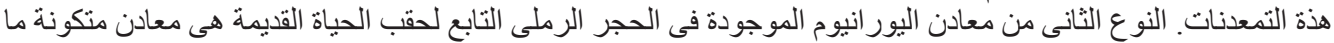

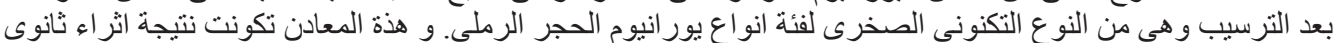

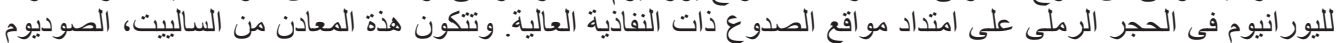

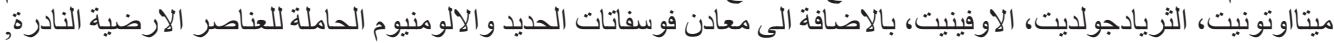
مثل الفيفيانيت، الجويازيت، الو افيليت، الفلورنسيت، بالإضيت، البلمبوجوميت.

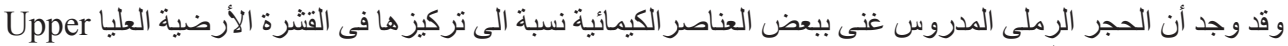
مثل : Continental Crust

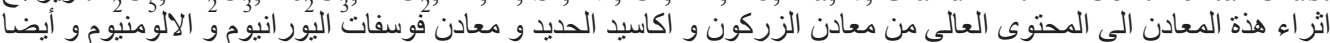

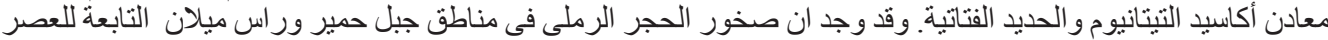

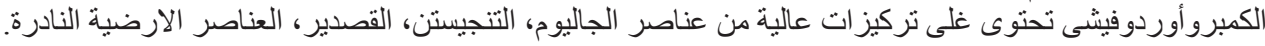

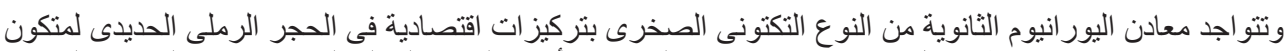

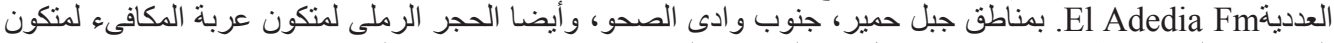

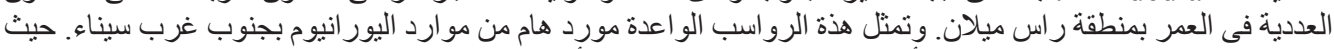

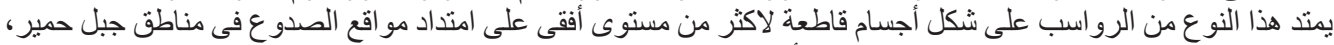

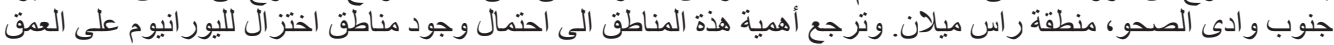

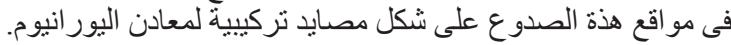

